2013

\title{
AGROFORESTRY ADDRESSING SOCIAL AND ENVIRONMENTAL ISSUES IN PARAGUAY
}

Brian T. Pattullo

Michigan Technological University

Follow this and additional works at: https://digitalcommons.mtu.edu/etds

Copyright 2013 Brian T. Pattullo

\section{Recommended Citation}

Pattullo, Brian T., "AGROFORESTRY ADDRESSING SOCIAL AND ENVIRONMENTAL ISSUES IN PARAGUAY", Master's report, Michigan Technological University, 2013.

https://doi.org/10.37099/mtu.dc.etds/659 


\title{
AGROFORESTRY ADDRESSING SOCIAL AND ENVIRONMENTAL ISSUES IN PARAGUAY
}

By

Brian T. Pattullo

\begin{abstract}
A REPORT
Submitted in partial fulfillment of the requirements for the degree of MASTER OF SCIENCE

In Environmental Policy
\end{abstract}

MICHIGAN TECHNOLOGICAL UNIVERSITY

2013

(C) 2013 Brian T. Pattullo 

This report has been approved in partial fulfillment of the requirements for the Degree of MASTER OF SCIENCE in Environmental Policy.

Department of Social Sciences

Report Advisor: $\quad$ Dr. Kathleen Halvorsen

Committee Member: $\quad$ Dr. Blair Orr

Committee Member: $\quad$ Dr. Hugh Gorman

Department Chair: $\quad$ Dr. Patrick Martin 



\section{$\underline{\text { Table of Contents }}$}

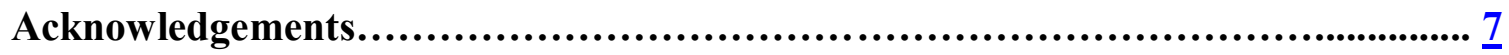

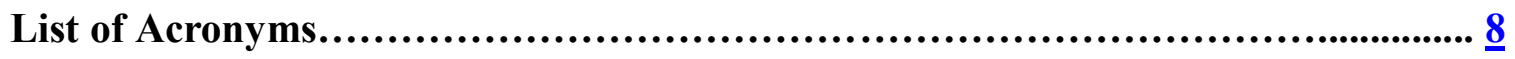

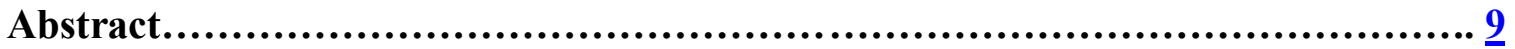

Chapter I: Introduction............................................................

Chapter II: Paraguayan Background.................................................. 11

i. Defining Periods in Paraguay's History ............................... 12

ii. Paraguay Today ...................................................... 14

iii. Deforestation and Environmental Issues in Paraguay......................... 15

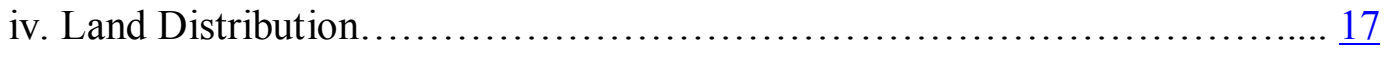

Chapter III: Peace Corps Agroforestry in Paraguay....................................................... $\underline{18}$

i. Peace Corps in Paraguay................................................... 18

ii. Libertad del Sur - The Freedom of the South............................ 20

iii. Prevalence of Soy and Questions of Appropriate Technology.................. $\underline{24}$

iv. Committees, Social Discord, and Expectations.................................. 29

Chapter IV: Peace Corps Agroforestry Volunteer Projects.............................. $\underline{32}$

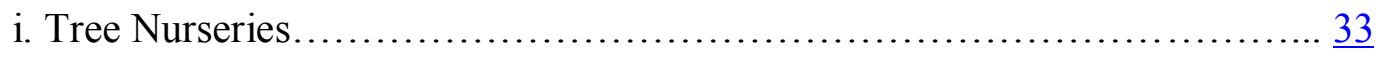

ii. Local Reforestation - Arborización................................. $\underline{38}$

iii. Agroforestry with Yerba Mate Project: Formulation...................... 42

iv. Agroforestry with Yerba Mate Project: Implementation.................... $\underline{45}$

v. Agroforestry with Yerba Mate Project: Investigation........................... $\underline{50}$

vi. Agroforestry with Yerba Mate Project: Evaluation........................... $\underline{53}$

Chapter V: Discussion............................................................ 
Bibliography.

69 


\section{Acknowledgements}

Thank you to my advisor, Kathleen Halvorsen, for your support and guidance from my first thoughts of joining the Environmental and Energy Policy program through to the completion of a five-year learning experience.

Thank you to my committee members, Blair Orr and Hugh Gorman, for their guidance and humor throughout the last several years. Your thoughtful insights and encouragement helped to put challenges in perspective and kept me focused on the bigger picture.

Thank you to the amazing "Green Team" leaders, Elizabeth Cabrera and Alistair Kerlin, of Peace Corps Paraguay. I owe the success of the yerba mate project to the wisdom, patience, passion, and dedication of you both and am grateful for the privilege of extending my service to work directly with you for a third year.

Thank you to Christine Hostettler, Celia Garayo and all of the staff of ProCosara. Your consistent support and hospitality towards me is greatly appreciated and you should be proud of the work you've done in communities around you like Libertad del Sur.

Thank you to Luis Maciel and his family, as well as the community of Libertad del Sur for the hospitality, dedication, hard work, and of course patience with me as I attempted to learn the language.

Finally, thank you to my family and friends for all of your support and encouragement as I've wandered through the last several years. Thanks for putting up with my stories. 


\section{$\underline{\text { List of Acronyms }}$}

BAAPA - Bosque Atlántico del Alto Paraná

Fondos - Fondo de Conservación de Bosques Tropicales Paraguay

GDP - Gross Domestic Product

Gs. - Guaranies (Paraguayan currency)

IBR - Instituto Bienestar Rural

INDERT - Instituto Nacional de Desarrollo Rural y de la Tierra

NGO - Non-Governmental Organization

PCMI - Peace Corps Masters International

PCPY - Peace Corps Paraguay

Pro Cosara - Pro Cordillera San Rafael

USFS - United States Forest Service

WWF - World Wildlife Fund 


\begin{abstract}
$\underline{\text { Abstract }}$
Paraguay is characterized in part by an economy reliant on a massive soy industry and as facing social and economic challenges resulting from highly inequitable distribution of wealth and land ownership, particularly for smallholder farmers in the rural areas of the country. Yerba mate (Ilex paraguariensis), a native tree of which the leaves are used in tea, has become an increasingly common crop grown among common among smallholder farmers (owners of 10 hectares or less) as a viable alternative to soy production on a small scale. In the rural agricultural community of Libertad del Sur, located in the heart of the severely deforested Bosque Atlántico del Alto-Paraná, a series of development initiatives including tree nurseries and agroforestry projects with yerba mate were implemented with involvement of several governmental and nongovernmental organizations. Research was conducted to identify effectiveness of an agroforestry strategy to promote reforestation activities and sustainable agriculture to achieve economic and subsistence goals of the rural population. Despite a severe drought impacting initial research goals, important lessons are considered regarding promotion of development work within the community as well as community perceptions towards development agencies. Pursuit of compromise between community member and agency goals using sustainable agricultural practices is identified as an effective means to promote mutually beneficial development strategies.
\end{abstract}




\section{Chapter I: Introduction}

In September 2009 I began my service as a Peace Corps Volunteer in Paraguay after having completed my first two semesters as a Peace Corps Masters International (PCMI) Student at Michigan Technological University pursuing two Masters of Science of Forestry and Environmental and Energy Policy respectively. After 3 months of technical and language training in Guarambare, Paraguay, I was assigned as an agroforestry extension volunteer to the rural community of Libertad del Sur in the Department of Itapua, Paraguay. Upon completing the standard two-year commitment to Peace Corps Paraguay (PCPY), I was selected to extend my service for a third year as Volunteer Coordinator in the PCPY office in Asunción. I accepted the position in the hope that it would allow me to continue personal research as well as improve my understanding of development work in Paraguay.

I consider my service successful in many regards despite setbacks and challenges that are common among Peace Corps volunteer experiences. I initially proposed to evaluate the success of individuals from my community in adopting formal yerba mate agroforestry systems. The outcome was anticipated to suggest appropriateness of an agroforestry strategy as a policy mechanism to promote sustainable agriculture and reforestation among smallholder farmers. However, a four-month drought resulted in high rates of plant and crop mortality and prevented achievement of those research goals. Despite this setback to my own objectives and those of the community, I am able to identify smaller successes and anecdotal evidence supporting the identification of appropriate strategic initiatives in promoting such environmental and socio-economic change among rural smallholder agricultural communities. 
The following report will identify these successes as well as provide recommendations for organizations and individuals conducting policy formulation, implementation, and evaluation in similar development work environments. Additionally, this report will consider many of the issues confronted throughout my volunteer service in the context of the lessons learned through the Masters of Science programs in the Environmental and Energy Policy and Forestry Programs at Michigan Technological University.

Among the lessons learned in the Environmental and Energy Policy and the PCMI Forestry programs was the importance of analysis of policy environments including a historical perspective. There are several factors in Paraguay's history that should be considered in order to understand the relevance of my work and that of Peace Corps, as well as the context of this report and the activities presented therein.

\section{Chapter II: Paraguayan History in context}

Many aspects of Paraguay's history throughout the past two centuries have resulted in current social, economic and environmental issues. Through devastating wars and corrupt leadership, an inequitable distribution of wealth and power has emerged and resulted in numerous growing conflicts over land claims and usage. Policies enacted to address land reform through the latter half of the $20^{\text {th }}$ century resulted in high rates of deforestation through conversion to agriculture. Current challenges for the country include addressing land reform for the rural poor without compromising land rights of large landowners responsible for much of the national income, as well as addressing social and environmental impacts of deforestation. 


\section{i. Defining Periods in Paraguay's History}

Since winning its independence from Spain in 1811, numerous events have created challenges to Paraguay's equitable social and economic development and have negatively impacted the quality of its environment. Of the more notable historical events is the triple alliance war from 1864-1870, in which Paraguay simultaneously fought Brazil, Uruguay and Argentina over boundary and regional political disputes. The result was the death of over $60 \%$ of the population including approximately $90 \%$ of the male population (Britannica, 2013). Prior to the war, $80 \%$ of Paraguay's territory was considered public lands. Following the war, from 1870 to 1915 , over $60 \%$ of the countries territory was sold primarily to British, Argentine, and Brazilian corporations in order to pay off war debts as well as to assist in repopulating the country (Rulli et al., 2006; Kleinpenning, 2009). While the population size has largely recovered to nearly seven million inhabitants today, the lasting cultural, economic, and political impacts are still being realized.

Through approximately thirty-four years Paraguay was lead by a dictatorship characterized largely by expansion and growth as well as corruption and human rights abuses. From 1954 to 1989 the leadership of President Alfredo Stroessner promoted land distribution policies aimed towards developing the agricultural industry of the country through sales of public and private lands as well as gifting public lands to his political supporters. The Stroessner era was characterized by institutional corruption utilized as a means of control to bind elites and public employees to the regime and perpetuate their allegiance (Nickson, 2002). In 2003, The Paraguayan legislature mandated the formation of a Truth and Justice Committee to investigate human rights abuses between 1954 and 
2003. One of the key findings was that wealthy Paraguayans and foreigners acquired $64 \%$ of their lands illegally during this period through government handouts or by seizure from campesinos who are commonly identified as relatively poor rural farmers (Stadius, 2012).

At the center of this debate are approximately 12 million hectares that were to be distributed to Paraguayan peasants through the governmental department Instituto Bienestar Rural (IBR), but were instead distributed to allies of Stroessner (Rulli et al., 2006). This debate is illustrated in the June, 2012 eviction by police and military forces of 60 landless campesinos in Curuguaty from a plot of 50,000 hectares originally dedicated to landless poor through the IBR program that were instead given illegally to former Senator Blas Riquelme in 1969. A campesino coalition argued that since Riquelme had illegally gained the property, it should be reverted to public lands to be distributed to landless Paraguayans. The conflict resulted in the death of 17 and is identified as the impetus for the 2012 ouster of then President Fernando Lugo for mismanagement of the situation (Dangl, 2012). The incident in Curuguaty highlights the status of the ongoing debate within the country and escalating national concern over the issue as well as the legacy of corruption regarding land distribution.

Many governmental policies enacted by the Stroessner regime damaged public confidence and trust not only in the government, but also among fellow community members. Stroessner-era policies aimed at limiting collective action among the populace included strictly limiting meetings of opposition parties and mandatory membership in the Colorado political party in order to be eligible for government work (Roquié, 1987). Stroessner utilized a network of community informants and secret police known as the 
pyragues to monitor any potential opposition forces (Winslow, 2012). It has been reported that as many as 1 in 4 Paraguayans were utilized as informants (Roquié, 1987). Subsequent to the coup that ousted Stroessner from power in 1989, a carefully documented "Archive of Terror" was discovered; a collection of over 700,000 items documenting systematic repression and violation of human rights spanning the 34 years in which Stroessner was in power (CDA, 2008).

It is important to consider the impacts of the preceding political history to understand the context of the current challenges to agricultural, economic, and social development at the campesino level in rural Paraguay. This description of Paraguay's history is provided to frame how policies' impacts have perpetuated distrust within communities and towards the government stemming from past land distribution and social policies. It is important to understand this historical context in order to fully appreciate the nature of needs and issues faced in rural Paraguay today.

\section{ii. Paraguay Today}

Paraguay remains a relatively poor country of nearly 7,000,000 people with an annual average per-capita income of approximately $\$ 3,100$ U.S. (CIA, 2013; World Bank, 2013). Primary contributors to the $-0.5 \%$ GDP are services (60.8\%), agriculture (19.8\%), and industry (19.4\%) (CIA, 2013). Primary agricultural crops include soy, of

which it is currently the $4^{\text {th }}$ largest exporter in the world, wheat, cotton, corn, tobacco, 


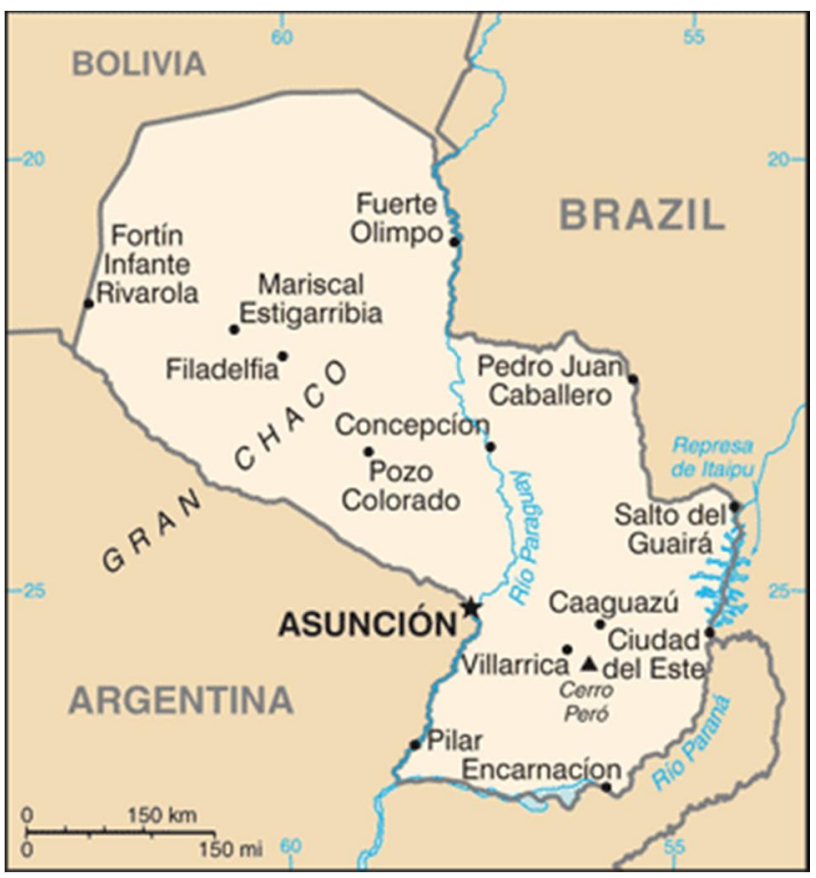

Figure 1: Map of Paraguay and surrounding countries. (Source: CIA 2013)

sugarcane, and beef. Approximately $40 \%$ of the population is identified as rural and largely agricultural based, and $60 \%$ urban. Poverty is a large concern as an estimated $34.7 \%$ are below the poverty line (CIA, 2013). Corruption continues to be a concern with the country as it is currently ranked $150^{\text {th }}$ out of 176 countries in Transparency International's corruption index (2013).

\section{iii. Deforestation and Environmental Issues in Paraguay}

The eastern region of Paraguay includes approximately 1.7 million hectares of the threatened Bosque Atlántico del Alto Paraná (BAAPA), a native subtropical forest shared with neighboring Brazil and Argentina. Approximately 93\% of the Paraguayan portion of the BAAPA has been deforested (HCVF, 2013). This region has been identified as a priority biological conservation area by organizations such as World Wildlife Fund 
(WWF) and Conservation International as it is home to an estimated 20,000 plant species, over 1,300 non-fish vertebrate species including over 530 bird species. Additionally, an estimated 6,000 plant species, $60 \%$ of the mammal species, $30 \%$ reptiles, and $90 \%$ forest amphibians found in this region are considered to be endemic (WWF, 2013; Huang, 2006).

Rates of deforestation increased significantly beginning in the 1970s, a change that is widely attributed to two main influences. First, there is a national perception of forestlands as unproductive areas of wild animals and obstacles to development of agriculture. Second, is the Stroessner era land reform laws that not only retracted ownership rights of 'unused' private forested lands, but also allowed for homestead claims to ownership. By clearing land and utilizing it for agriculture, an individual was entitled to a government-recognized title-less claim (Huang et al. 2006; Hetherington, 2009). These policies essentially resulted in a race to clear land in order to claim it by campesinos, who typically laid claim to 10 ha family plots, and larger landowners who cleared vast tracts of the land they had gained through legal and illegal claims before others could clear it and establish a homestead claim.

The process of attaining legal documentation of a land title was more complicated than the act of clearing it to establish an informal claim. Representatives from the IBR were expected to measure plots and create a derechera (a legal document with the owner's name and plot location) that officially identified the land claim on paper, regardless of whether the land was expropriated or actually purchased from a private landowner (Hetherington, 2009). The owner of a derechera was then responsible for paying quotas on the land to the government with annual harvests. Though the sale of 
derecheras is technically illegal, many transfers have occurred with written authorization of IBR officials. Once the quotas are fully paid, the owner is then entitled to an official land title. Sale of titles is prohibited legally within the first ten years after receipt by the landowner in order to limit self-dispossession of land by campesinos (Stadius, 2012).

Given the complexity of issuing derecheras and title documentation to lands that were claimed under highly variable circumstances with varying degrees of legitimacy of documentation, it has been a challenging process for the government to determine true ownership in many cases. In 2004 the IBR was officially renamed and restructured into the Instituto Nacional de Desarrollo y de la Tierra (INDERT) as the government concluded that the IBR's policies failed to meet demands of agrarian reform in providing not only titles, but also performing its role of establishing basic services such as water, electricity, schools etc. (INDERT, 2013). INDERT continues to be overwhelmed by demands to identify true ownership of disputed lands that may have up to three separate title claims to ownership for the same parcel (Stadius, 2012).

\section{iv. Land Distribution}

There exists a highly inequitable distribution of wealth and land ownership in Paraguay. Only $1 \%$ of the population owns $77 \%$ of the productive agricultural lands while $83 \%$ of Paraguayan campesinos, the rural poor, occupy approximately $6 \%$ of the productive lands (Palau et al. 2007. Howard, 2009). Approximately $40 \%$ of the country's population is rural and earns less than the average per-capita national income of U.S. $\$ 3,100$ (Correa, 2008). One impact of inequitable distribution of wealth and land has been in land price inflation to levels beyond the reach of the majority of Paraguayans. In 
the eastern part of the country, dominated by mechanized soy production, foreign investors offer up to 30 times that which campesinos would consider local market value (Hetherington, 2009). The majority of large soy producers in Paraguay are foreign owners from Brazil, Argentina, Europe, and Southeast Asia. Estimates of rates of foreign soy production ownership vary widely, some indicate 90\% Brazilian ownership while estimates of Paraguayan ownership only reach 24\% (Leite da Costa, 2011; Rulli, 2006).

\section{Chapter III: A Peace Corps Agroforestry Volunteer Reality}

Peace Corps volunteers work in highly diverse environments around the world. The Peace Corps program has evolved and adapted over the last 50 years of operation within the country to meet the changing needs expressed by the government. This chapter highlights the working situation experienced in a rural community as a volunteer trained specifically as an agroforestry extension worker.

\section{i. Peace Corps in Paraguay}

Peace Corps is a United States Governmental agency that has sought to meet training needs of 139 countries through voluntary service of Americans since its formation in 1960 (Peace Corps, 2013). Peace Corps programs in each country are adapted to address the diverse needs expressed by individual inviting host countries. Volunteers serve a total of 27 months including an initial 3-month required training orientation period in their respective countries of service. This training typically includes language and technical aspects relevant to their work sector, as well as much of the 
background political history and issues volunteers commonly confront during their service.

Peace Corps has operated in Paraguay since 1967 and currently focuses volunteers' training and objectives in agriculture, education, economic development, health, and environmental education sectors. I was in the last group to receive training as an agroforestry volunteer. This sector focused efforts on integrating trees into agricultural landscapes primarily among smallholder farmers in rural communities, as well as general tree planting wherever feasible. This sector was combined with environmental education in 2010 as part of an agency-wide initiative to focus work sectors on themes that volunteers have reported greater rates of success in implementation. The majority of agroforestry volunteers in Paraguay had reported low success rates of project implementation and community reception to core work activities in which volunteers were specifically trained.

Volunteers experience a wide variety of issues within the communities to which they are individually assigned. To account for this variety, a broad and uniform introduction to the country's history and the social, economic, political, and environmental issues facing the country is provided to all training groups. The relevance of issues presented during pre-service training such as land reform impacts, foreign investment in mechanized agriculture, and working with partner organizations is of varying utility depending on the nature of volunteers' respective communities. These latter aspects of the training proved highly useful in explaining many of the issues that I encountered in my particular assigned community. 
The role of a Peace Corps volunteer in a community can be considered similar to that of a street level bureaucrat such as a teacher, police officer, or other community level implementers of policy. The nature of a street level bureaucrat's role requires them to be directly involved in the lives of their clients using their knowledge and skills to secure for their clients the best treatment they can within the limits of their resources (Lipsky, 1980). Peace Corps recruits individuals with backgrounds they deem appropriate to a respective countries demonstrated needs and trains them in technical, cultural and language skills relevant to that country. These individual volunteers are then placed in communities where at least one resident has specifically requested Peace Corps volunteer presence. The volunteer is granted discretion to assist their assigned community however they see appropriate, ideally within the framework of the training they had received and their background experience. Peace Corps does not provide financial or commodity resources to volunteers in order to implement projects within their communities. As volunteers are not granted much more than moral, technical and networking support in fulfilling work duties within their community, it is up to the individuals to discover creative ways to identify needs and provide service to their community clients.

\section{ii. Libertad Del Sur - Introduction to The Freedom of the South:}

I arrived in my new community of Libertad del Sur on December 16, 2009 as the second Peace Corps volunteer in 3 years. Following up another volunteer relieved some pressure since the rural community was already accustomed to some of the differences between cultures. 
I was introduced and given a free $400 \mathrm{~km}$ ride to my community with representatives of an NGO based in the capital, Asunción, who had been doing some work in the area in promotion of tree nurseries, tree planting, and purported organic agriculture. During this trip, I was shown several projects that they reported as successful in promoting tree planting and reforestation goals. However, over the next two years, I came to see their work methods as creating a challenge to my own work and that of any other outsider seeking to help the community. Due to the long distance from the capital to the community, following up on their own work and understanding community nuances proved to be challenges for them. This resulted in a disconnect from the realities of the social impacts of their efforts and a reluctance on behalf of many within the community to work with such outside organizations.

Several stops on this preliminary community tour highlighted unsustainable and inequitably beneficial projects. As we viewed a tree nursery that didn't produce trees but was more of a store-house for tree seedlings grown in a separate location, it was evident that the seedlings were over-matured and roots had outgrown the limits of the poly bags. Upon inquiring around the community I came to realize that few individuals even knew of the tree nurseries existence and even fewer knew that they could solicit trees for free. When explaining the nurseries purpose in the community, which was to assist in local reforestation by providing free native trees, community members were still reluctant and often indicated that the nursery was located on private property of a leader from an agricultural committee who was not part of their social group. An organic agriculture project was limited to one farmer's 10-hectare plot, coincidentally owned by the same farmer who owned the land where the tree nursery was located. A tree-planting site we 
visited proved to be a good example of mixing native trees, citrus, eucalyptus, and subsistence crops that had been established approximately three years prior. However, this example too was located on the property of a leader from the same small committee.

I came to realize that this NGO focused their efforts on a small segment of the population and presented it as community building to representatives of their funding organization, the U.S. Forest Service (USFS), who were traveling with us to observe what reforestation results the NGO was achieving. Subsequent conversations with community members reflected negatively upon the NGO and the committee. It was frequently expressed by community members that they thought the work this organization did was largely for show in order to continue receiving funds, and benefits were limited to friends of the NGO. This initial exposure to the community served to frame much of the community perception towards outside organizations' form of assistance, and conversations resulting from my arrival with the NGO suggested a common skeptical attitude towards my own presence.

Libertad del Sur is a small community roughly 40 kilometers from paved roads consisting of about 140 families spread out across 4 parallel roads each approximately 5 kilometers in length. The first settlers here arrived in the late 1970s taking advantage of the land reform policies to claim their 10 ha parcels and building their houses from the local forests they cleared. Today it is a farming community surrounded by large-scale foreign owned mechanized soy farms. The average family has about 5 members in the household and average landholding is 7.5 hectares.

Most families earn their income by working for the large-scale farmers in the area for approximately 40,000 Paraguayan Guaranies per day (4,500 Gs. $=\$ 1$ U.S.), as well as 


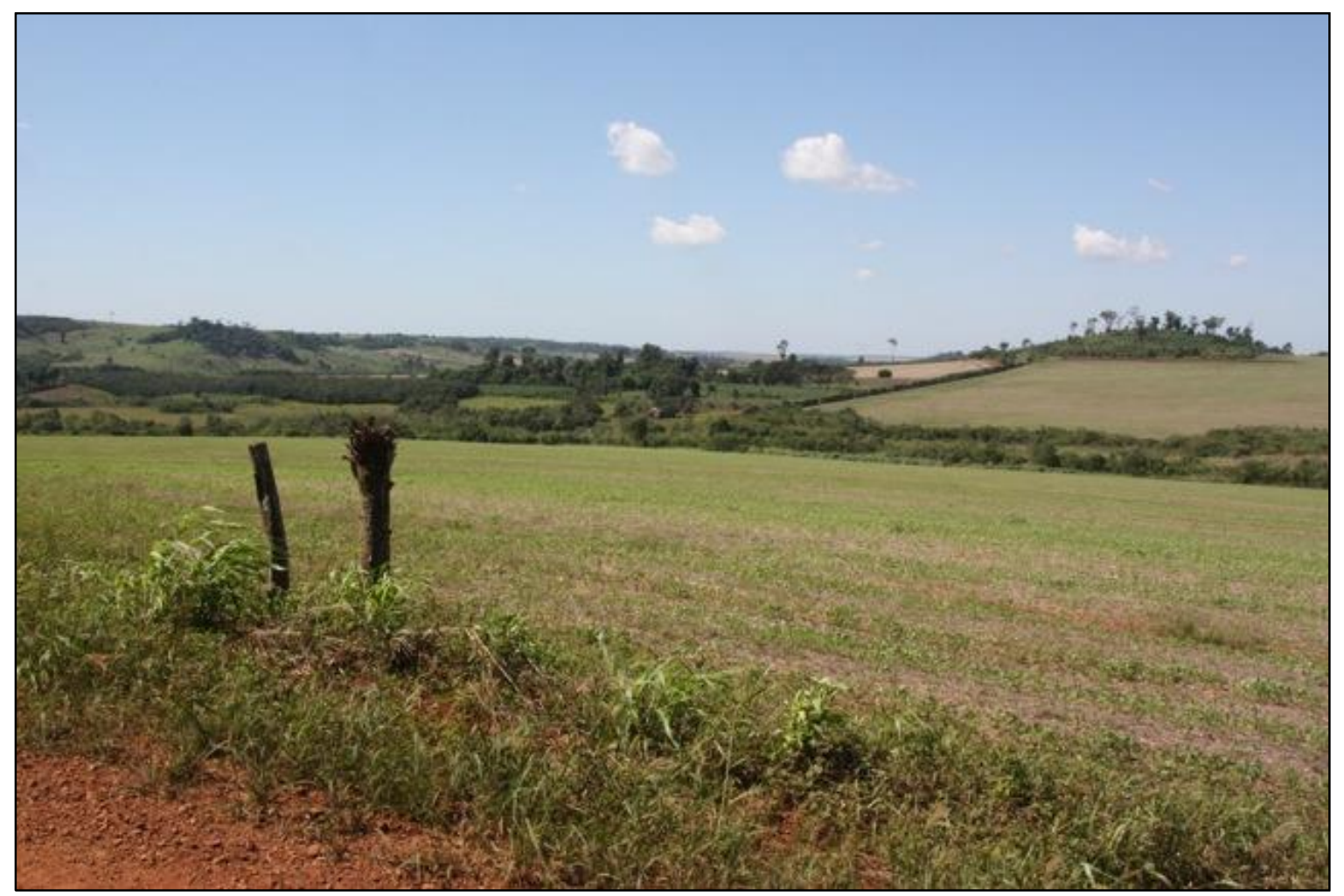

Figure 2: Libertad del Sur. Mechanized agriculture forming the Western border of town. (Photo by Brian Pattullo)

producing cash crops such as soy, wheat, citrus, and tung on a few hectares of their land. The majority reserve at least 1 or 2 hectares for cultivation of subsistence crops including cassava/mandioca, corn, beans, peanuts and a few assorted subsistence crops. Most families own at least a few chickens, some have pigs, and fewer have 1 or 2 head of cattle. There are a few despensas (small stores) scattered throughout the community that sell basic supplies of milk, meat, rice, flour and a few household items such as laundry brushes and plastic bowls but little else. The majority of the households use fuelwood (wood burned for cooking and heating purposes) as the primary energy source, well above the national average use of fuelwood at $20 \%$ of household energy consumption (DGEEC, 2013). 
Through informal conversations with community members an array of past failed projects promoted by outside organizations were identified. The organizations included NGOs such as the example described previously, as well as companies that promoted projects such as citrus farming among the campesinos but failed to provide follow up technical assistance and ultimately resulted in loss of crops and confidence when insects and fungus impacted some plots. The community had also been waiting at least 2 years for a governmental water project that would bring running water to the community, though communication with agency representatives had apparently dissolved. While I was present in the community I was witness to several other NGOs and governmental organizations that promoted farming projects such as a poroto japonesa (Japanese bean), an edible nitrogen-fixing bean. The organization promised to return to purchase the products following harvest from willing participants. However, after 4 months they, like many other organizations in the past, failed to follow through. The result was that local farmers were left with a crop for which they had sacrificed their time, effort, and land and had neither a final market to sell to nor a taste for the bean itself.

\section{iii. Prevalence of Soy and Questions of Appropriate Technology}

The interaction of environmental, cultural, educational, political, and economic conditions determine the developmental needs of each country. The perception of what developmental needs exist is often variable between governments, communities, development organizations and industries based on their respective objectives. 


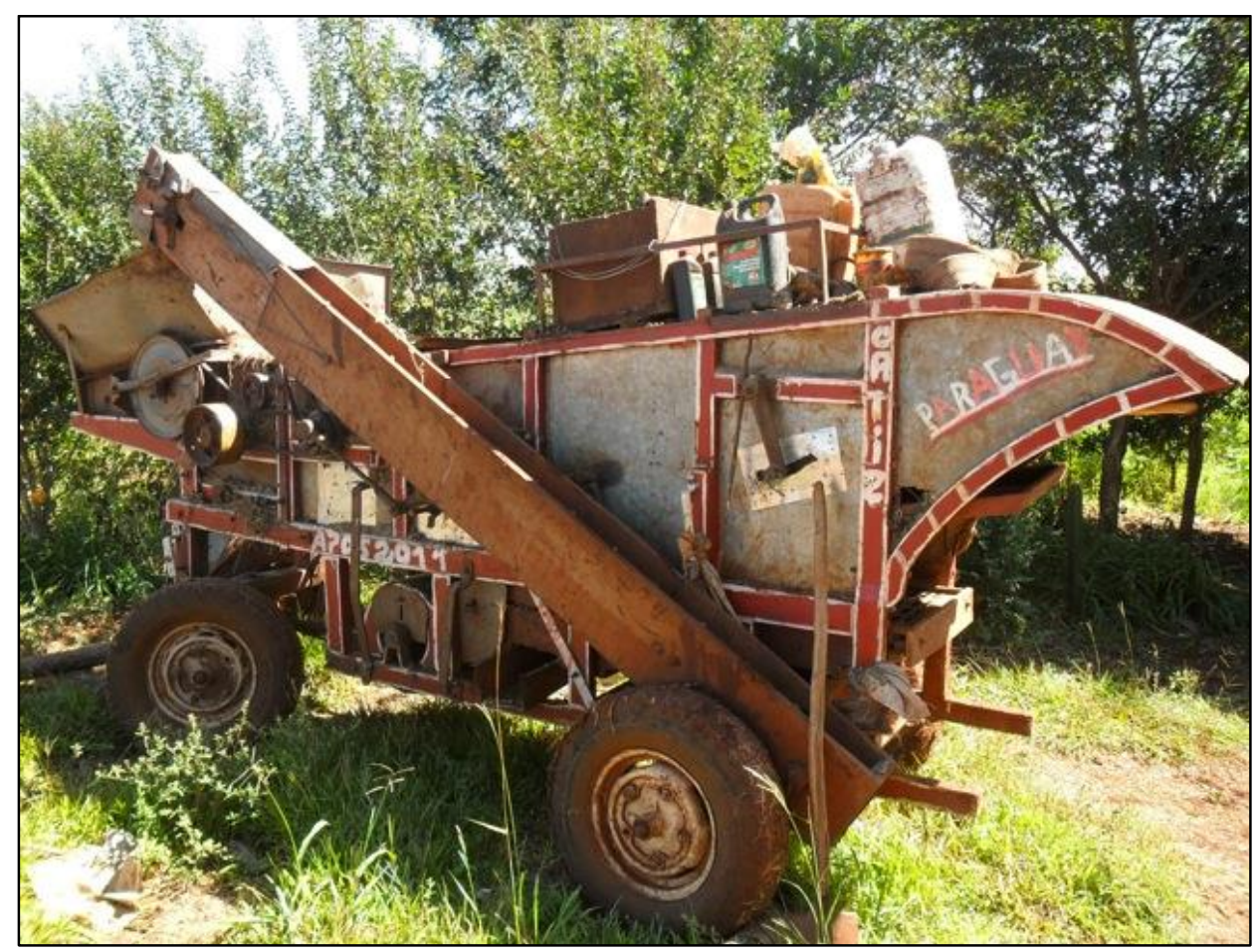

Figure 3: Old style tractor still in use by smallholder farmer. (Photo by Brian Pattullo)

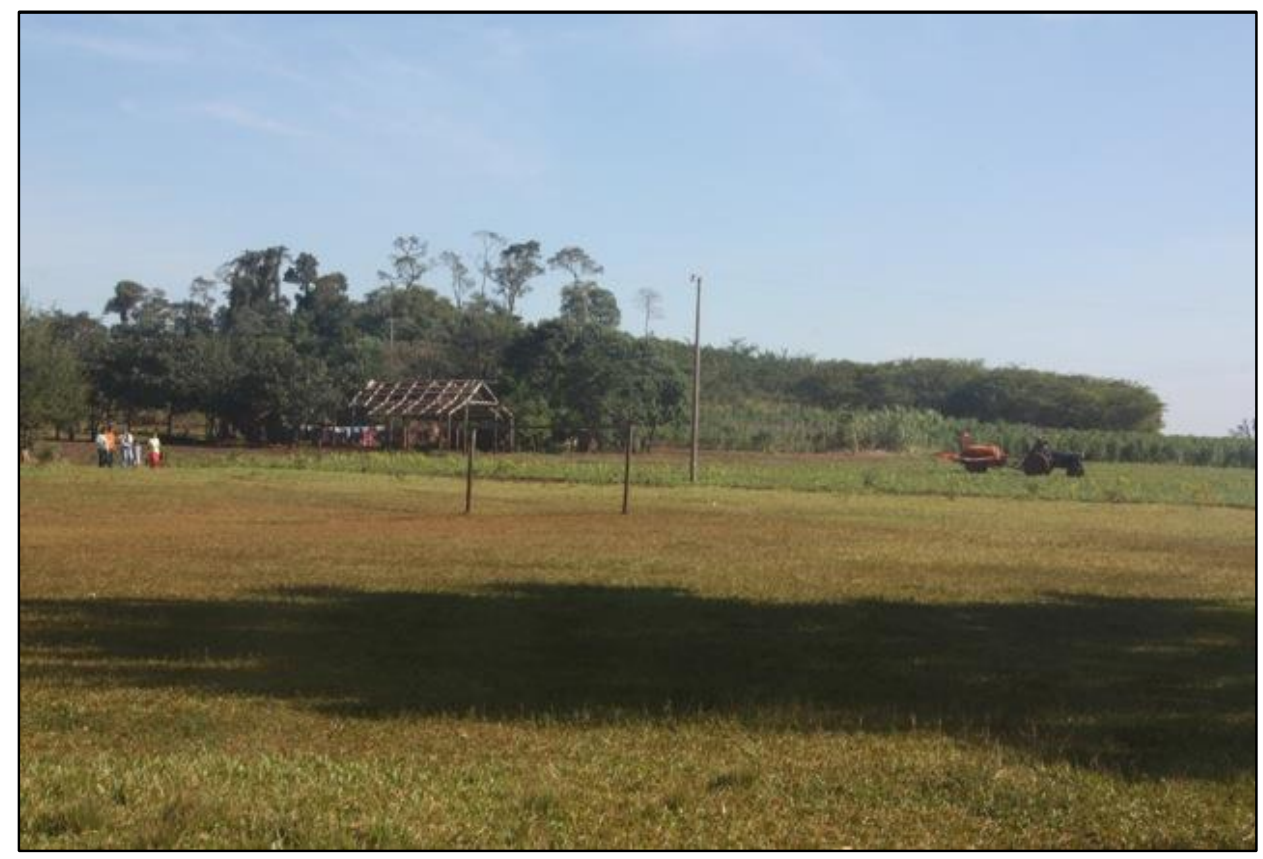

Figure 4: Hired tractor applying pesticides near smallholder farmer house as residents walk on road. (Photo by Brian Pattullo) 
Understanding the complexities that shape the national and cultural paradigms is crucial in formulation of policies at the national and local levels to influence adoption of development programs and technologies appropriate to achieve equitable distribution of benefits and costs of policy implementation (Evans, 1979). What is considered 'appropriate' technology is largely based on the perspective of the entity promoting it. For the purposes of this report, appropriate technology is considered in its ability to achieve equitable distribution of benefits as well as costs.

The rapid integration of soy into the landscape can be seen as evidence that the country is a suitable environment for the soy industry to meet rising global demand for cattle and livestock feed, as well as the growing agro-fuel industry in Europe (Abramson, 2009). National governmental agricultural policies welcomed the industry, and the national GDP has grown as a result. However, the industry has presented numerous negative consequences for segments of the population. For example, nationally between 1990 and 2009 it is estimated that 100,000 smallholder farmers have migrated to urban areas already experiencing high unemployment, and an estimated 9,000 farmers are 'evicted' from their lands annually by soy production (Abramson, 2009). Eviction has included the buyout of smallholder farms by larger producers, as well as forced eviction of landless Paraguayans squatting on private property. Many rural individuals have attributed their need to relocate to health risks associated with the prevalence of agrotoxins used heavily on mechanized farms that frequently surround communities.

The dominance of soy in the national market has limited the ability of smallholder farmers to remain competitive in soy production and maintain a livelihood, thus resulting in increased urban migration. In the community of Libertad del Sur, many of the 
smallholder farmers with whom I worked frequently identified their inability to earn a reasonable income from soy on their relatively small sized property. During a formal interview one married couple explained the situation as follows:

Wife: "So we don't plant soy because it's expensive for the seeds, for the pesticides..."

Husband: "For it to work first you have to do the preparation (of the land with a tractor), then the spraying, look for pesticides, the quantity of pesticides that you have to find... Then there are some people who will apply them incorrectly and it doesn't go and it will take all your money. So it's better to rent the land." (Informant 1-12-11)

These statements are a good representation of the standard attitude towards soy among smallholder farmers within the community. Several smallholder informants indicated that it was common to only earn 1,000,000 Gs (\$220 U.S.) per hectare from soy, and even if the full average 7.5 hectares are planted to soy it is still below the national average income (Informant 1-10-11).

A lack of understanding regarding the proper use of pesticides is also of concern among many community residents, though there is a notable contradiction between stated concerns and actual practice. I frequently observed individuals, including small children, operating backpack sprayers in their fields wearing only shorts, flip-flops, a t-shirt and a hat with no respiratory protection. These were often the same individuals who in conversation would discuss their concerns with the widespread spraying on mechanized farms surrounding the community and potential risk to their family's health and wellbeing. 


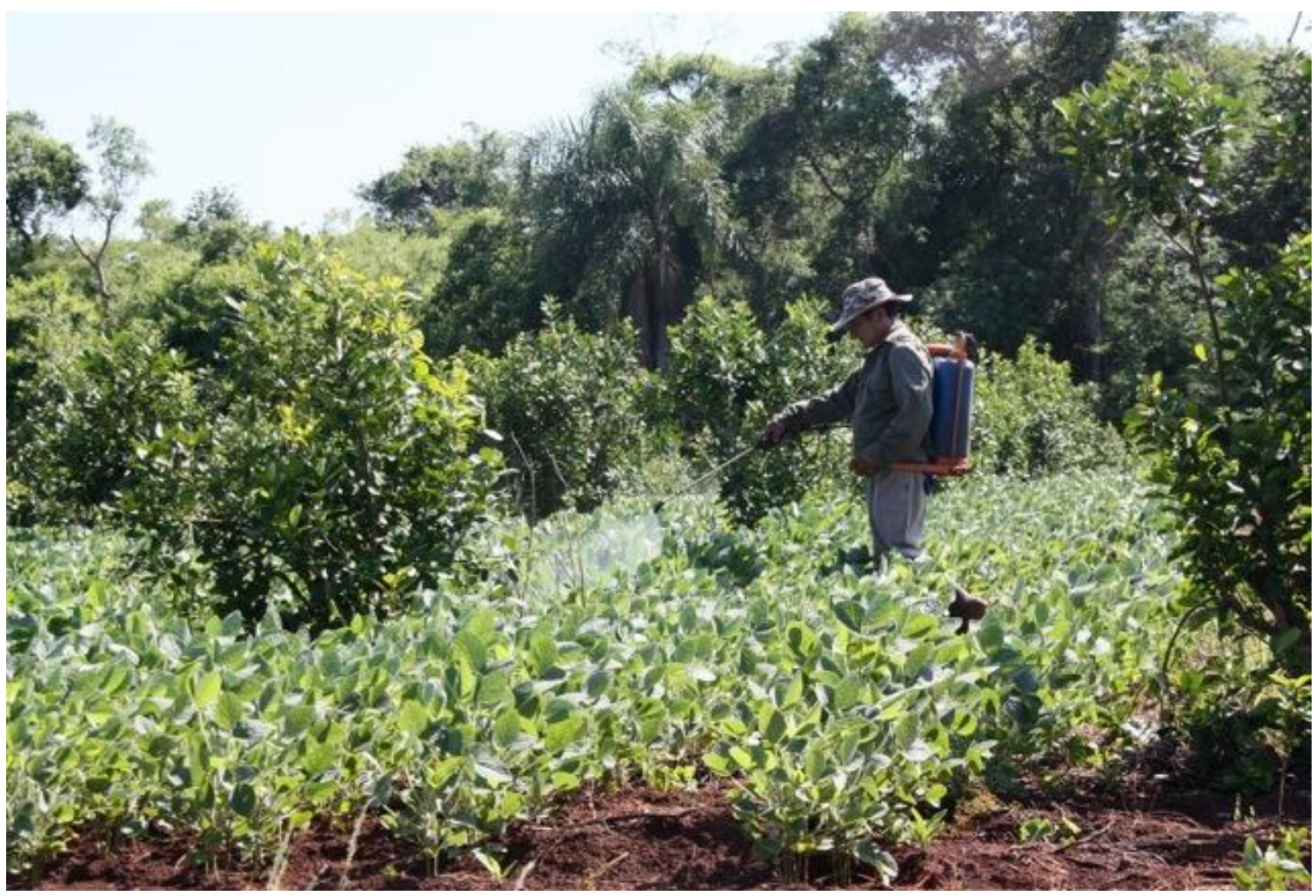

Figure 5: Hired worker manually applying pesticides. (Photo by Brian Pattullo)

It is estimated that the soy industry utilizes over 6 million gallons of pesticides every year including some that have been classified by the World Health Organization as extremely hazardous and illegal in the U.S. and the E.U. such as 2,4-D, Gramoxone, Paraquat, and Endosulfan (Abramson, 2009). Individual cases and anecdotal evidence of increasingly frequent incidents of birth defects, cancer, and other health concerns attributed to the soy industries use of these pesticides raises the question of how to equitably distribute the benefits as well as the costs of the growth of the soy industry in Paraguay. 


\section{iv. Committees, Social Discord, and Expectations}

I identified three separate men's farming committees and one women's committee at varying degrees of formal establishment early in my service and made efforts to attend their meetings and get to know their objectives, hopes and challenges. I quickly came to find that the groups were at odds with each other, and eventually identified two primary underlying issues as justification: land and resources.

In Paraguay, committees commonly form for similar reasons as those that I was told by a member of the most recently established group:

"If we are a formal group, it is easier to get things from the government." -Anonymous

I witnessed one project promoted by the Ministry of Agriculture that supplied shovels, rakes, pesticide applicators, seed-sewing tools, as well as 10kg bags of seeds to a women's committee who had solicited their help. Several of the families didn't even own one full hectare of land sufficient to plant the quantity of seed provided. Many individuals mentioned selling the materials they had been given since they needed money more than the equipment. Other competing committees within the community who did not receive any of the benefits from this governmental organization argued that they were in greater need and frequently mentioned this event in their frustration with political influence shaping support in the region. Many community members indicated that the group that received the benefits was of the same political party as the leadership directing the Ministries regional office. 
In my second week in Libertad del Sur I attended a meeting of a committee that had expressed interest in working with me. When I inquired as to what sorts help I may provide the list included a soccer field, soccer jerseys for a 'community' team, sewing machines (so they could make their own jerseys), a tractor and a health post. While some of these items would indeed be useful, they were inconsistent and indicated a lack of clear direction of a group whose mission statement focused on promoting agro-ecological farming practices within the community. This example also illustrates a challenge of participatory planning and suggested to me that identification of community needs might be better performed through individual conversations. Further involvement with this organization on my behalf was limited largely to mutual frustration regarding my inability to meet their expectations.

These examples indicate a challenge for others and myself in similar roles in managing expectations. In considering the root of conflict, Charles Malik (1966) wrote:

"one of the principal causes of both international conflict and internal strife is unfounded expectations. These are based ultimately either on deception or on a belief in magic."

As I became aware of the community expectations of outside organizations, as well as from myself, and saw reactions when I explained the inability to appease them, I began to feel the weight of Malik's statement.

These early interactions highlight several common issues of working with groups, particularly in areas where resources are limited. Asset distribution inequality can lead to conflict, up to and including violence (Deininger et al., 2000). Land distribution inequality is a common concern in Paraguay and Libertad del Sur is no exception. Shortly after my arrival in the community, members of one committee had sought legal action to 
evict an individual from another committee from their property because of the dilapidated nature of their house. The committee members had solicited representatives of INDERT (the land titling authority) to revise boundaries that would have redistributed land claims for this and other questionable properties within the community. As the individual in question did not possess a physical title, but rather the simple establishment of residence, calling the dilapidated state of the residence into question was sufficient to raise the question of legitimacy of his land claim. These actions solidified an already competitive and conflict oriented relationship between committees, as well as a palpable contempt for members of the opposing groups.

The divide between committees was exacerbated through solicitation to outside NGOs and governmental organizations for assistance. The result of each successful request for help was an assumed definition of alliance with aid agencies. Only one committee worked with representatives of the Ministry of Agriculture, one with the Asuncion based NGO, and one with the local NGO. In practice, the groups did not cross these boundaries and were each very protective of their relationships with their respective aid organization.

Due to committee conflict, I was limited in my ability to serve the community as a whole as members of opposing groups refused involvement in projects connected to their rivals. During my two years in Libertad del Sur I attempted numerous projects involving all groups simultaneously and only those that required attendance for receipt of project benefits proved successful in attaining participation of individuals from all groups.

Despite overlapping commonly stated values and goals of competing groups towards improving lives of their fellow community members and promoting a cleaner 
environment through agro-ecological farming practices, conflicting paradigms regarding political party alliance and asset distribution equality prevented either from achieving their group objectives. In order to accomplish anything at the community level I, or any other street level bureaucrat, would need to exercise discretion in achieving a compromise between my own values and objectives, those of Peace Corps, those of the individuals and groups I sought to help, and those of any outside organizations that would be involved.

\section{Chapter IV: Peace Corps Agroforestry Volunteer Projects}

Peace Corps volunteers are encouraged to evaluate their community carefully before implementing any projects. This evaluation is intended to result in activities that will be based on a more thorough understanding of community dynamics as well as provide an opportunity to understand disparities between real and expressed needs of a community. Volunteers are encouraged to identify individuals and/or groups from within their communities with whom they feel comfortable developing a professional relationship. After completion of a volunteer's two-year service commitment and departure from their community, those community members will ideally be prepared to continue and expand on their projects and serve as a model for the rest of the community. The voluntary continuation of a project by community members is potentially an effective measure of the suitability of a project's strategy and objectives in achieving a community's development goals. The following chapter will describe and evaluate several implemented throughout my Peace Corps service in Libertad del Sur and highlight some successes and failures. 


\section{i. Tree Nurseries}

Upon my arrival in Libertad del Sur, I was introduced to the local NGO Pro Cordillera San Rafael (Pro Cosara), which is managed by a Swiss couple who had immigrated to Paraguay in the 1970s having purchased a sizable tract of the forested BAAPA. As they observed the deforestation in the region their growing concern resulted in their establishing the NGO dedicated to monitoring their property as well as that of fellow private landowners of the 73,000 ha San Rafael Reserve.

In efforts to increase the strength of their stakeholder group, Pro Cosara also performs some community development and environmental education activities in communities surrounding the reserve. One of these projects was the promotion of three community tree nurseries with one of the three committees in Libertad del Sur. However, participants cited concerns regarding their ability to share workloads and equitable distribution of efforts and rewards. Thus, the project was revised to provide 8 individual families from that committee the necessary supplies such as plastic shading, water tanks and plumbing/irrigating equipment to establish individual tree nurseries.

Pro Cosara's original project intent was to promote native tree production and community-wide plantation through provision of nursery equipment and training. The nursery operators were expected to produce native trees as well as whatever other marketable tree species they desired. In exchange for the nursery resources, the tree nursery operators were expected to provide a portion of their native tree production free to fellow community members.

During the first year all participants produced a combination of native trees and yerba mate (Ilex paraguariensis), which is a native tree species with important cultural 


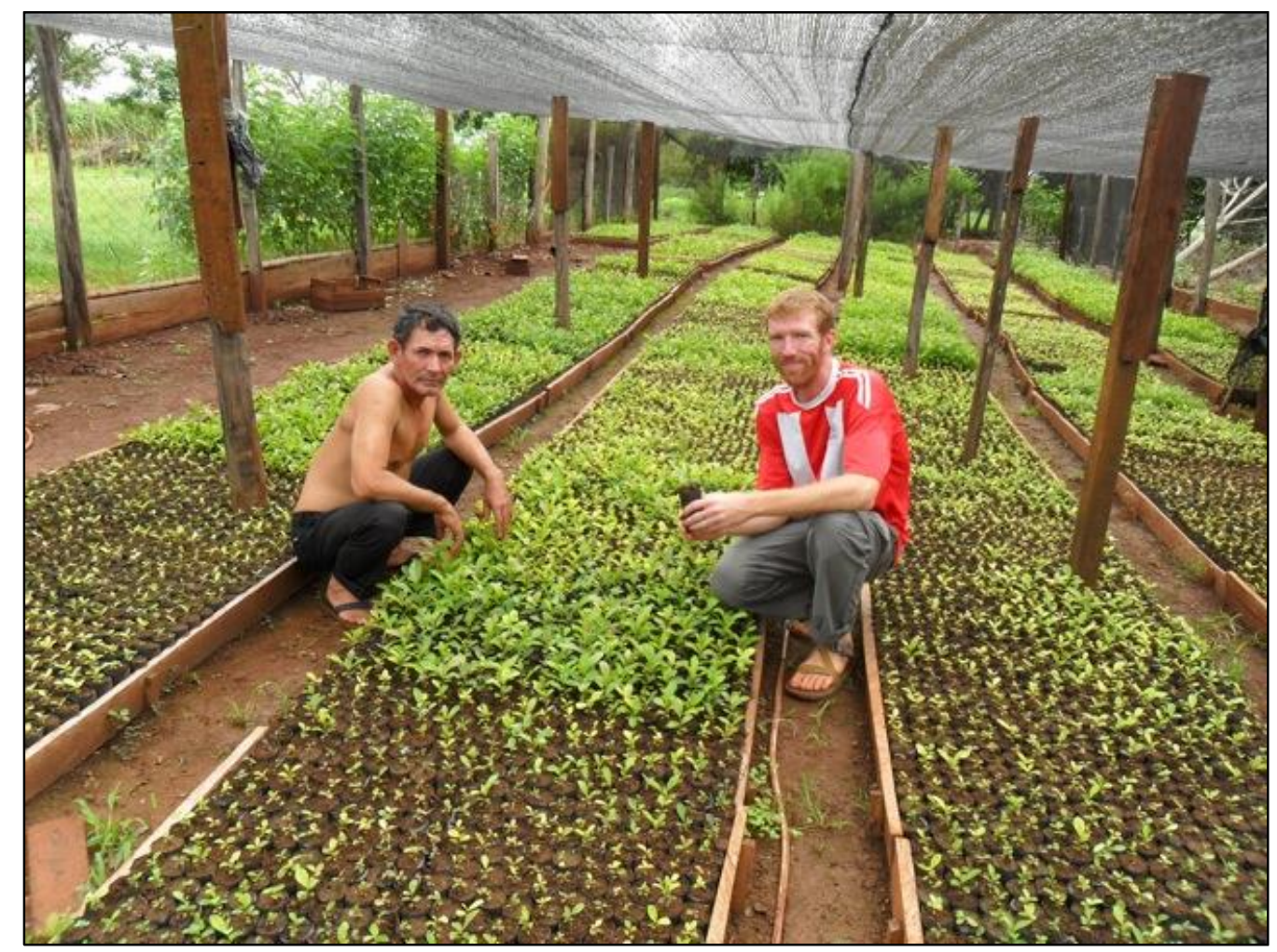

Figure 6: Brian and nursery operator in early yerba mate growth stage. (Photo by Brian Pattullo)

and economic value in the region for its use as a tea. I worked closely with a representative from Pro Cosara to provide technical training, follow-up assistance to the participating individuals, as well as coordinate necessary supplies and general motivational support.

Some nursery operators were initially hesitant to invest in the project since it is a large commitment of time and energy to maintain yerba mate seedlings for the 15 months required to achieve marketable size. However, in spite of this challenge, after two years seven of the eight nurseries were producing between 3,000 to 50,000 plants per year. At least three were integrating eucalyptus, and one was specializing in producing several thousand native and exotic tree seedlings of higher demand and more limited supply than 


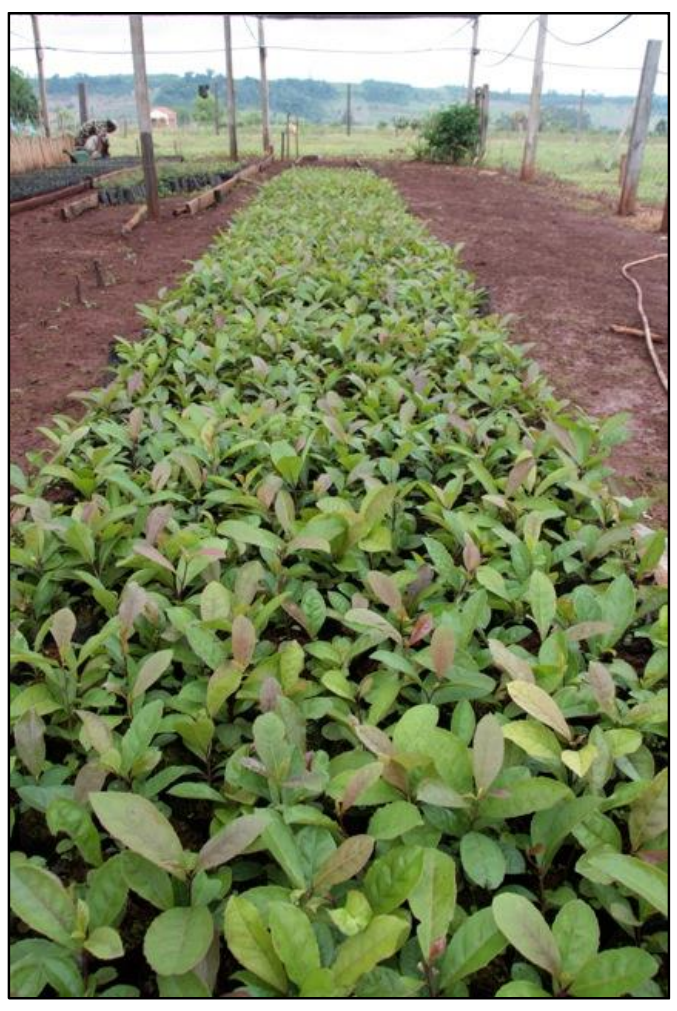

Figure 7: Mature yerba mate seedlings in nursery, approximately 12 months old. (Photo by Brian Pattullo)

what were available in the region. Given the market value of 800 Gs per plant, the largescale nursery operators had potential income of between $2,400,000$ to $40,000,000$ Gs. (\$530 to $\$ 8,500$ U.S.) annually.

Several individuals outside of this committee expressed interest in learning to establish their own yerba mate nursery. To satisfy this demand I worked with the tree nursery operators to develop a one-day yerba mate nursery training open to all community members. Twenty-two participants attended and worked together on constructing a very small $1 \times .5$ meter seedbed in a corner of the school garden. The school offered a neutral ground that minimized connection to any particular groups or 


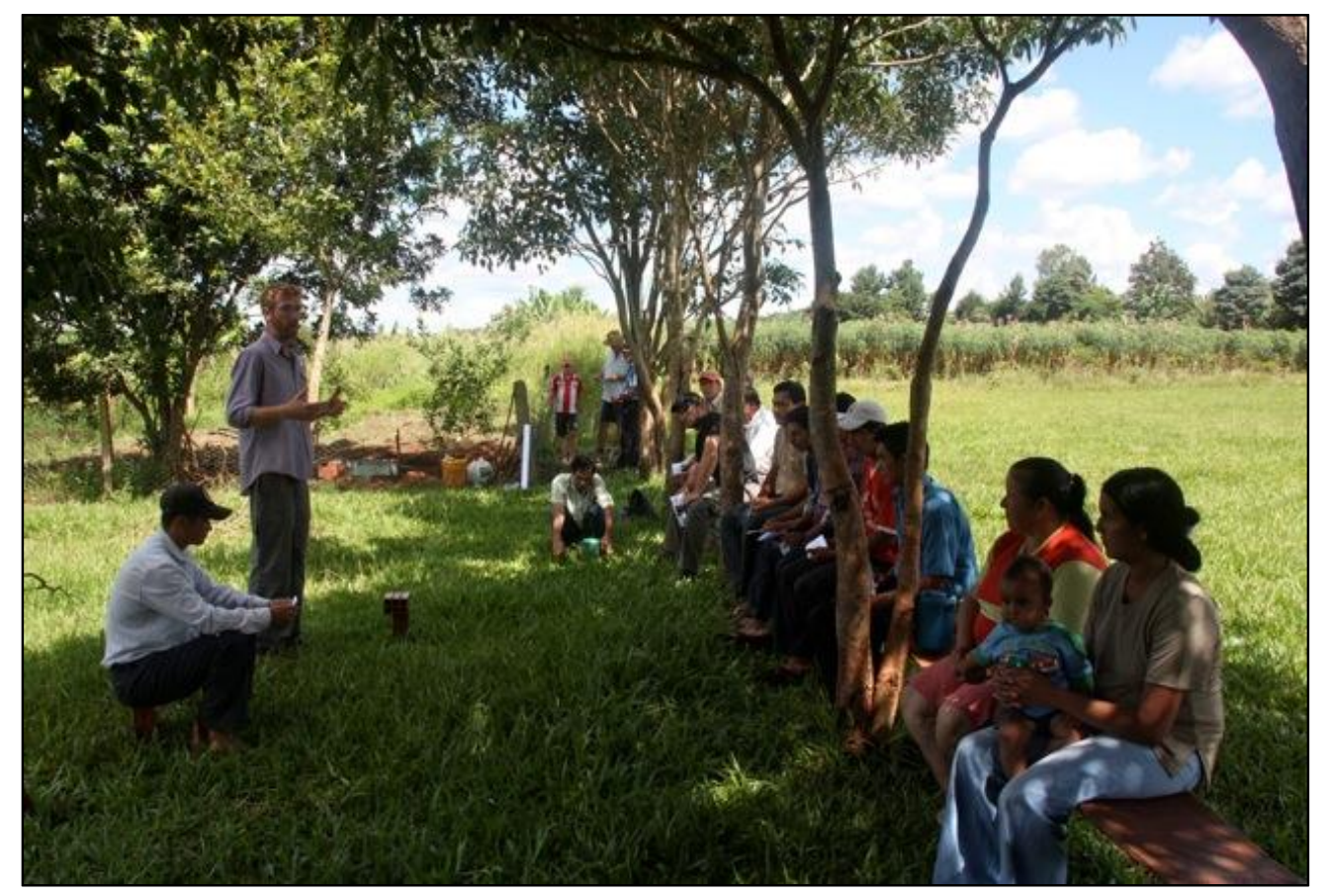

Figure 8: Introduction to the topic and rationale for small nursery establishment during the yerba mate tree nursery voluntary training. (Photo by Brian Pattullo)

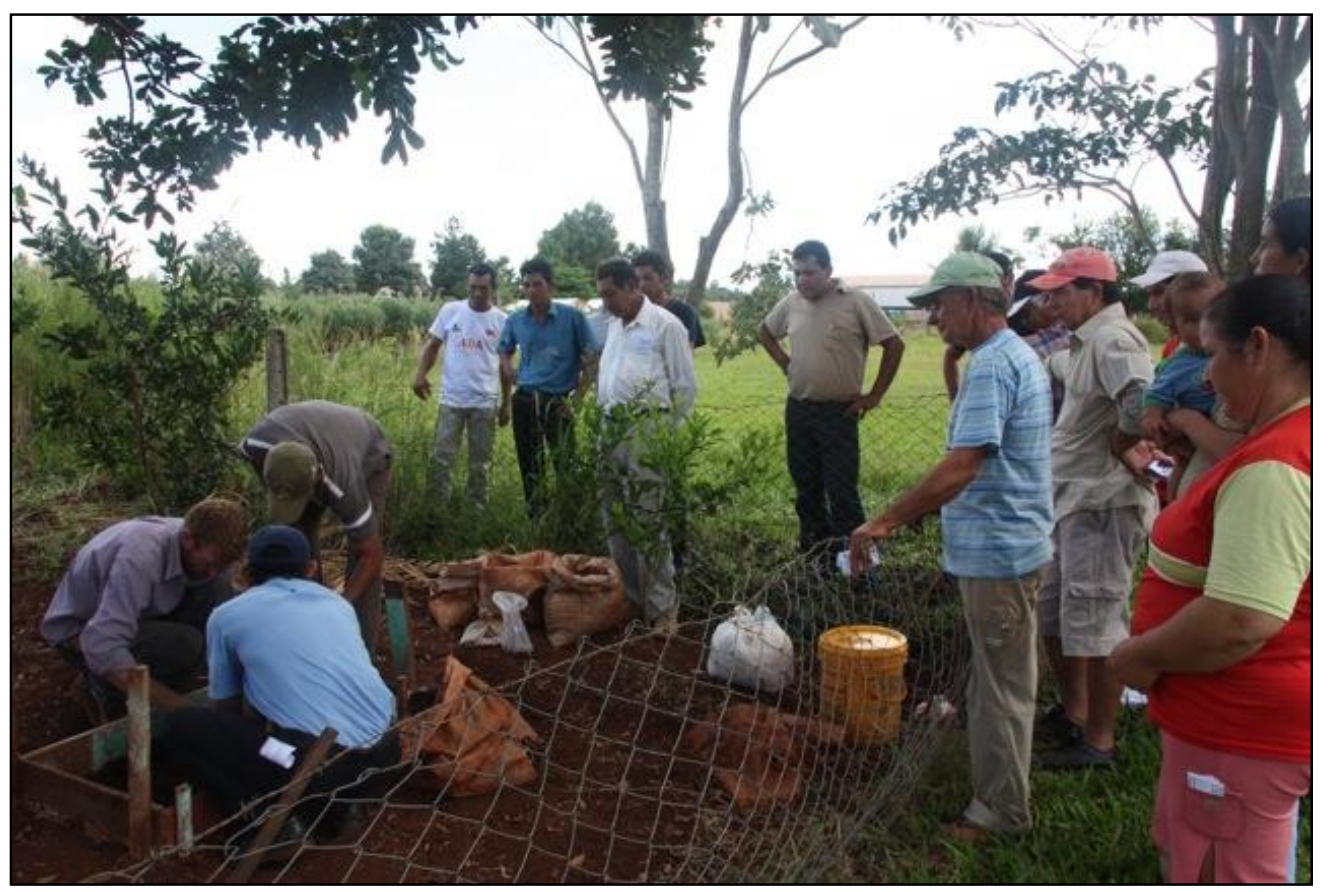

Figure 9: Group activity of creation of small-scale nursery during the yerba mate tree nursery voluntary training. (Photo by Brian Pattullo) 
individuals from the community. Following this training, at least 5 individuals began their own small-scale yerba mate nurseries. Follow-up technical assistance was also provided by myself and offered by members of the tree nursery committee. In house-tohouse visits at the end of my service I identified an additional 5 yerba mate nurseries that had begun independently with the help of participants of this nursery training.

While Pro Cosara's tree nursery project was successful in introducing sustainable income generating activities to a segment of the population, it was a failure in one of the key objectives of the funding NGO. Pro Cosara intended to promote community reforestation by training and equipping individuals within the community to produce native trees that were to be given free to fellow community members. Participants failed to follow through with providing these native trees for a variety of reasons. First, many community members were unaware of the availability of free trees. Second, demand for native trees was already satisfied by periodic free tree distribution projects arranged by Pro Cosara with native tree donations from A Todo Pulmon from nursery sources outside of the community. A Todo Pulmon was unable to purchase native trees from nursery enterprises that were not officially recognized by the Paraguayan governmental tax authority, and the nursery operators in Libertad del Sur were unable/unwilling to successfully navigate the bureaucratic process of attaining that legal certification. Regardless of the reason, the end result was that many of the nursery operators disposed of their native trees that had outgrown their macetas (poly bags) and refused to plant trees for which there was no demand.

Pro Cosara ultimately ceased providing financial and commodity support to the nursery operators as they failed to follow through with their obligations of providing 
locally free native trees. These examples of tree nurseries within the community illustrate overlapping goals between funding organizations and community members in establishing locally sustainable income generating sources of native plants. However, the two groups conflict in perception of the project objectives between that of reforestation and development of an alternative income source.

\section{ii. Local Reforestation - Arborización}

In the first few months within my community I followed up on the work of a previous volunteer who had been successful in the distribution of approximately 5,000 native trees donated by A Todo Pulmon and delivered with the help of Pro Cosara. This initial work served to identify the local native tree demand and served as the impetus for the promotion of Pro Cosara's tree nursery project within the community. I conducted a house-to-house survey within the community to identify demand for native tree seedlings. This survey provided me with an excuse to approach each household and get to know the community, a task that is otherwise potentially awkward as a new Peace Corps volunteer with limited language abilities and minimal understanding of the true nature of their role in the community

Working with the help of a nearby volunteer, 111 families were identified that wanted 13,911 native trees and 9,858 eucalyptus trees. All native trees and only about 1,500 eucalyptus were distributed between May and September of 2010. The eucalyptus was not delivered in full because it is an exotic species in Paraguay and not in accordance with their institutional reforestation objectives. However, this was in contrast to 
community members' goals of utilizing fast growing tree species that provide valuable timber and fuelwood that would reduce demand on remnant native forests.

While it is difficult to gauge the success of this tree distribution project since there was no direct follow up evaluation of tree seedling plantation, through subsequent visits to each household I can confidently say the majority of the tree seedlings were planted and survived for at least the initial 2 years. However, I observed many poorly planted trees, areas of high mortality, and several households that failed to even plant many of the seedlings that they received. The project also served to quantify demand for yerba mate within the community as the majority of households requested it specifically in response to questions probing interest in specific tree species.

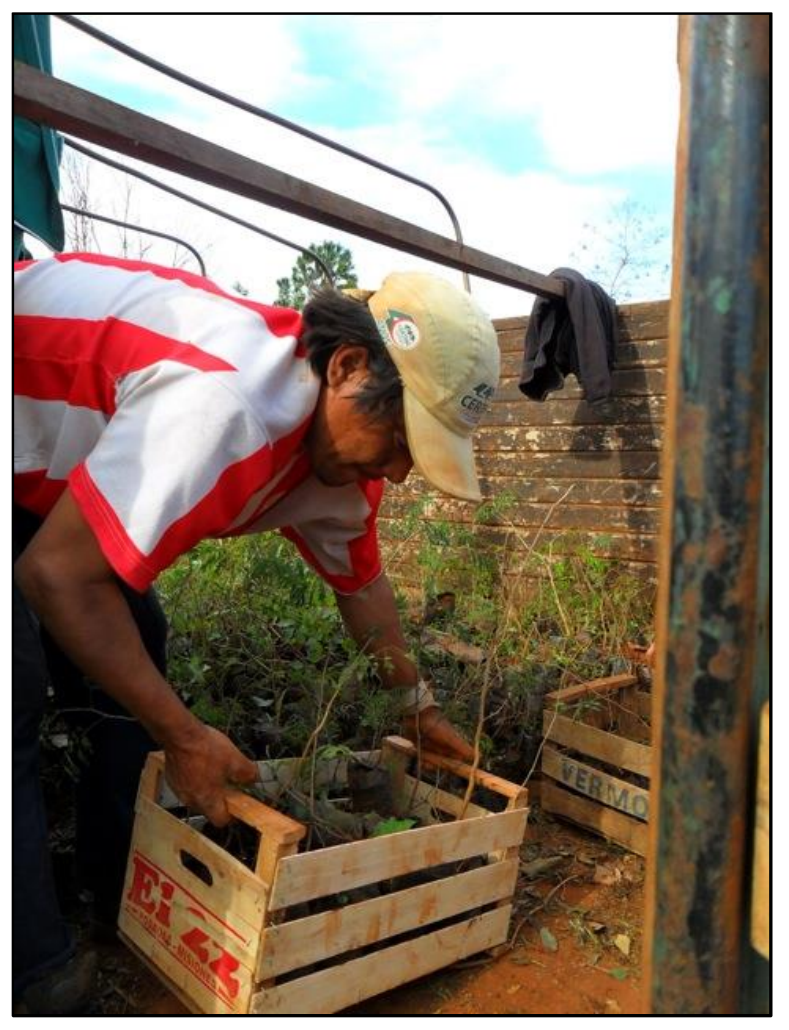

Figure 10: Native tree delivery one box at a time. (Photo by Brian Pattullo) 


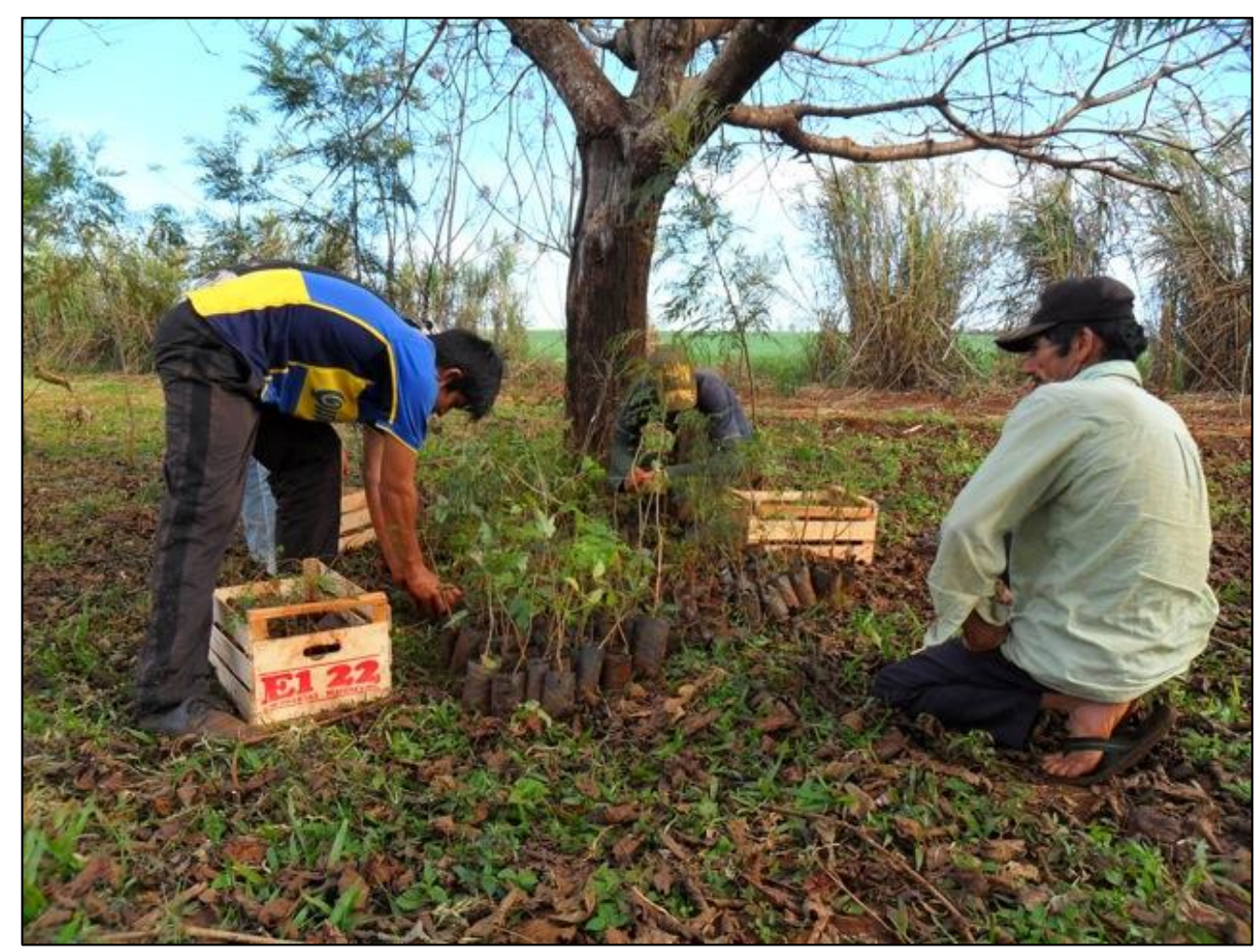

Figure 11: Volunteers helping with household delivery. (Photo by Brian Pattullo)

One primary challenge was in managing community expectations of the project.

When the previous volunteer had distributed trees, individuals who received and planted trees were rewarded in cash from Pro Cosara just before Christmas of the same year. Perhaps this was an underlying cause of the doubling of demand between the first volunteer's survey and my own. When I performed a tree survey I was frequently asked if there would be a financial reward for participation. Despite statements that funding was not available, there remained an expectation among community members. Shortly before the following Christmas holiday I was asked with increasing frequency when families could expect their reward for the trees that Pro Cosara planted on the community members' properties. Failure to follow through on meeting expectations when a 
precedent existed resulted in a risk to the project objectives reflected in the following statement from a prospective tree nursery operator:

"If Pro Cosara doesn't give me a water tank then I am going to pull up the trees that I planted for them on my property." - Anonymous

This individual expected to be provided more free resources based on his own past participation in the organization's efforts as well as what others had received in the first year of the nursery project. Failure to follow through on meeting participants' expectations jeopardized the success of the organization's subsequent projects.

The reforestation project was successful in distributing trees, but perhaps a greater value is in the understanding gained through the process regarding goals of the community concerning agriculture and the environment in general. Many individuals indicated frustration with soy production such as challenges of earning a reliable profit, a desire to plant a more valuable crop such as yerba mate, and perceived limitations to planting more trees for fear of undesirable competition for resources with traditional crops in finite land.

This project also clarified the nature of many individuals' motivation to participate and raised questions regarding what are reasonable incentives to promote actions desirable to funding organizations. A disconnect was highlighted between smallholder farmers in the community and environmental organizations where the former desired productive, profitable land with minimal work inputs and the ability to meet demand for otherwise increasingly expensive fuelwood. The latter focused on tree planting and educational programs in order to reduce pressure on remnant native forests 
and promote a cultural paradigm shift towards increased appreciation of the natural environment.

\section{iii. Agroforestry with Yerba Mate Project: Formulation}

In Libertad del Sur I saw the opportunity to integrate yerba mate that was being produced locally and was in high demand by the majority of the community, native trees that were produced and donated free of charge from nearby organizations, and a community that was mired in a cycle of diminishing returns from soy.

Yerba mate seedlings sell locally at a unit cost of 800 Gs. (\$.18 U.S.). Utilizing a general planting density of 1,600 units/ha the total per hectare cost is approximately 1,280,000 Gs. (Approx \$280 U.S.). This cost is exacerbated when considering that the plants will not yield a harvest until at least the $3^{\text {rd }}$ year, and an optimal harvest won't be achieved until year 7 . Once matured, however, the average plant will continue to yield leaves of a desired quantity and quality up to 30 years. Estimates are variable, but many participants indicated they could produce $10,000 \mathrm{~kg} /$ ha of yerba annually and sell it for $850 \mathrm{Gs} . / \mathrm{Kg}$ (approximately \$.19 USD), which could yield up as much as 8,500,000 Gs./ha annually (approximately \$1889 USD) (Informants 1-13-11, 1-18-11). After 30 years, plants are typically replaced or the field is converted to other crops as the farmer desires. The majority of the farmers saw this as a risky long-term investment of their already scarce resources.

I was notified of a funding opportunity with the organization Fondos de Conservación de Bosques Tropicales Paraguay (Fondos) whose stated mission is to promote conservation, management, and restoration of tropical forests within the country. 


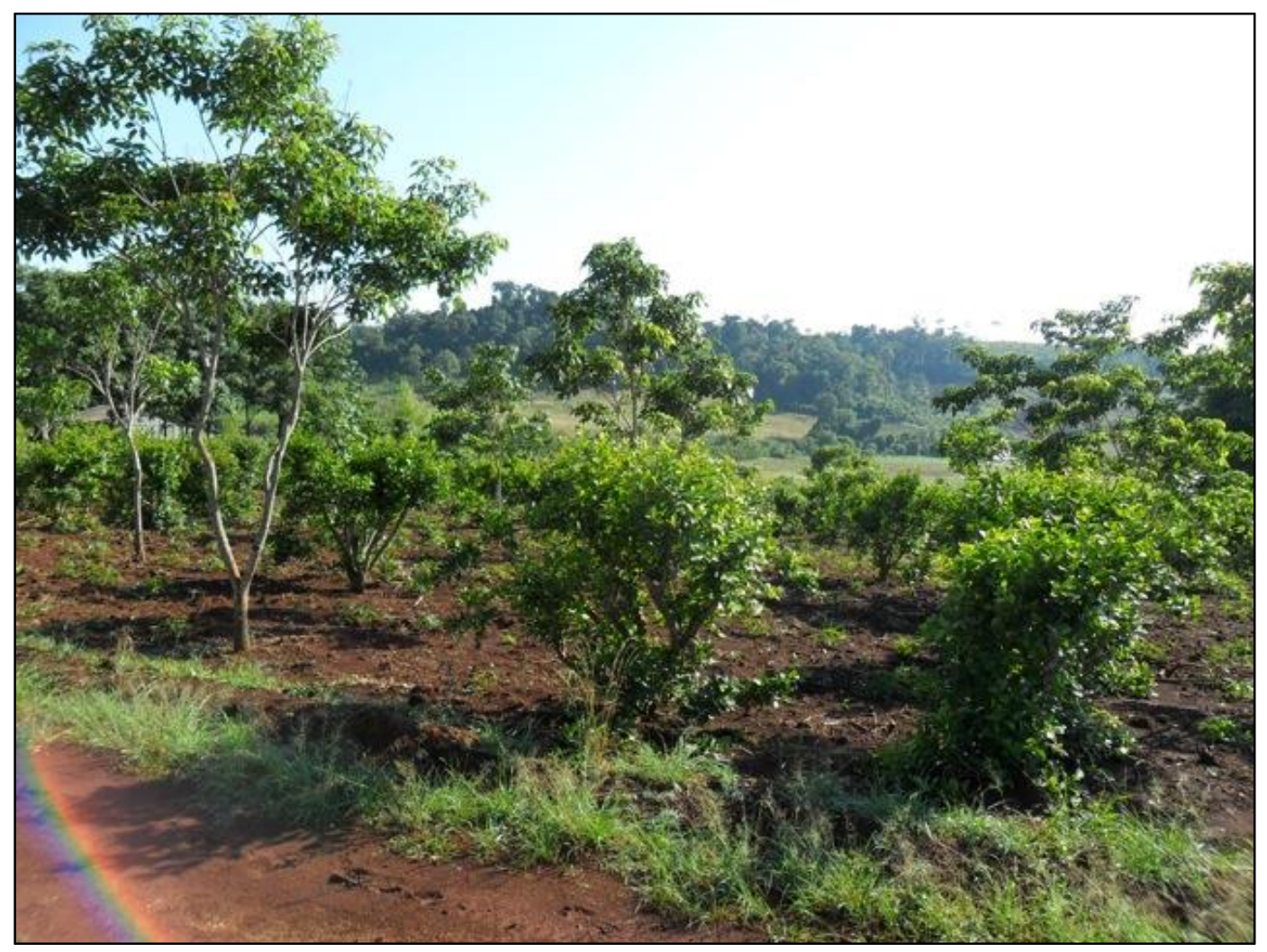

Figure 12: Example of 10-year old yerba mate with native tree agroforestry system (Photo by Brian Pattullo)

Working with my Peace Corps sector director and other staff members, we applied for a $\$ 10,000$ U.S. grant to fund a project that would promote sustainable agricultural systems incorporating locally grown yerba mate, native trees, and subsistence crops allowing smallholder farmers to maintain productive land through the initial three to five years until the yerba mate was financially lucrative. The project's goals included providing an opportunity to begin conversion of up to $1 / 2$ hectare for each farmer, promoting a greater understanding and appreciation of the value of trees to the environment, reducing fuelwood demand on remnant forests by integrating more trees into the agricultural landscape, and promoting integration of subsistence crops with yerba mate and native 
tree cultivation to minimize perception of sacrificing land to long term investment crops. This project was unique from past projects within the community in that it was offering free benefits to anyone, which emphasized a theme of community building that was explicitly discussed in all project related events. By working together as a community to develop their market strength in yerba mate, they were more likely to have access to more desirable markets for product sale as well attaining technical assistance.

This project sought to achieve many of the organization's objectives as well. Through a series of trainings, the project promoted environmental education regarding the importance of preserving remaining natural forest stands including planting more trees to alleviate resource pressures on those forests. Establishment of more trees in the agricultural landscape would also achieve the organization's goals of preserving biodiversity in the region through biological corridors linking fragmented remnant forest stands. Additionally, the increased promotion of agroforestry with yerba mate would result in less agrotoxin pollution in waterways because yerba mate typically does not require pesticides and far fewer fertilizer inputs than the regionally dominant soy crop.

A requirement of the application was that the solicitation must be on behalf of a legally recognized committee from within the community. There were three committees present in Libertad del Sur that did not work well together, and only one had the necessary legal documentation. This situation presented a challenge of identifying a strategy to attain goals that would benefit the entire community while minimizing potential conflict by involving individuals as well as leaders from all committees. I was reminded of what Earl Babbie writes regarding conflict (1994. pg.163): 
“...none of our harmonizing can take place except among individuals who are fundamentally separate, different, and, to that degree, in conflict with each other."

Despite my reservations and concern of involving myself with community controversy between committees, I focused the project's overall objective to benefit the entire community. I sought the support of the legally recognized committee to satisfy Fondos requirement of an official signing beneficiary. In an effort to minimize potential conflict I explained to this signing committee that their role was as project advocates within the community. The yerba mate was to be purchased locally from members of the committee operating the eight family tree nurseries. Pro Cosara would manage funds, and I accepted responsibility for organizing trainings, household surveys, delivery, and evaluation. This was admittedly not an equitable distribution of responsibility, but given social dynamics I determined it most appropriate for the benefit of all. Additionally, the project proposal was not discussed with anyone else from within the community until and unless it was approved by Fondos to minimize community expectations and potential for conflict generating rumors.

Though the preliminary application was denied, Fondos suggested revisions of the project to focus on meeting their organizational mission and objectives as opposed to our focus on social welfare and sustainable agriculture. The project was revised to include four formal required trainings provided by local experts focusing on deforestation, habitat, biodiversity, watershed protection, national reforestation efforts, green manures, and agroforestry with yerba mate. Fortunately, in February 2011 we were granted the $\$ 10,000$ U.S. and thus began my very busy second year of volunteer service. 


\section{iv. Agroforestry with Yerba Mate Project: Implementation}

Upon funding approval from Fondos, I immediately began another house-tohouse survey to identify quantities of yerba mate plants desired by each family. Participants were allowed to specify a specific quantity though the majority requested the maximum available that would be determined by a function the final plant prices and the number of participants. In order to receive maximum benefits of the project, the participants were required to attend the four trainings as well as one day of community service that either involved assisting in one day of tree distribution or one day working in the community's school garden.

A total of 94 families signed informal contracts stating that they agreed to the terms of participation and would plant all seedlings on their own properties. Verification of planting was conducted by myself, and penalties for non-compliance included forfeiture of plants or the requirement to reimburse the project for the full cost of all plants provided to the individual household.

Quantities of plants for each individual were determined on a sliding scale based on participation in three trainings and one day of volunteer service. The final training event attendance was not considered in calculations because plant distribution began prior to the event in order to coincide with the ideal planting season. Thus, participation in four events received maximum benefits. Individuals participating in four events received 800 yerba mate plants, three events received 700 , two events received 600, one event received 500, individuals failing to participate in any events received 210.

Everyone received an automatic $10 \%$ equivalent quantity in native trees, consistent with the recommendations of planting density for appropriate mature tree canopy shading and 
root competition avoidance. This incentivized participation was effective as reflected in attendance levels of 47, 73, 68, and 32 in training events one through four respectively. The initial training attendance was low primarily because of inclement weather and assumed cancellation of the event as per the norm for the community. The last event received low attendance presumably because distribution had already begun and people failed to see the incentive in continued participation. In total 62 service days were completed by the participants. However, several of those days were repeat volunteers exceeding the minimum 1-day of service. Individuals who participated in extra days were rewarded with extra plants. Several received 925 plants in total, and one who participated nearly every day with delivery receiving 1,050 as well as my sincere personal gratitude.

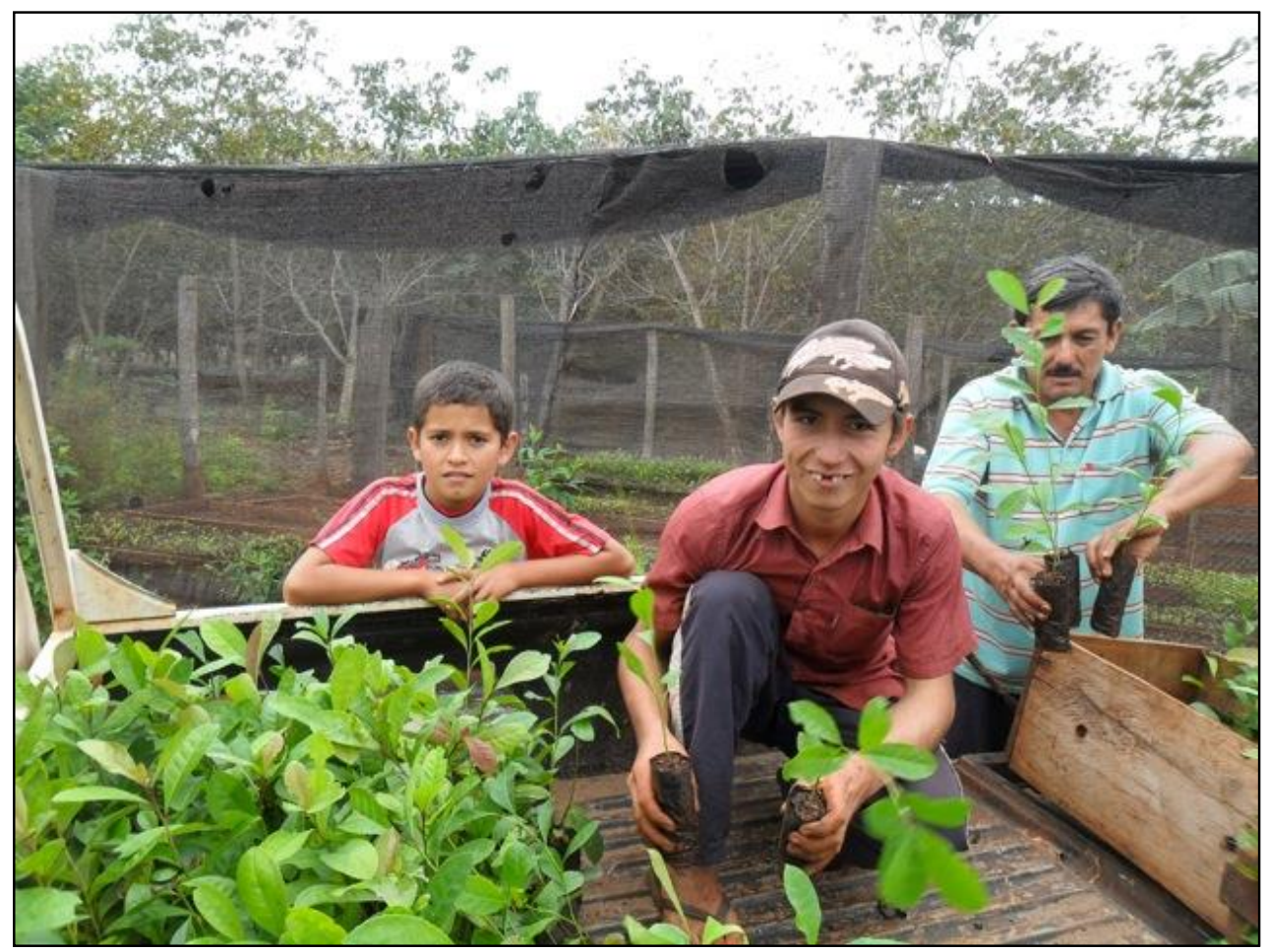

Figure 13: A family with their own personal vehicle loading yerba mate seedlings for themselves and their neighbors. (Photo by Brian Pattullo) 


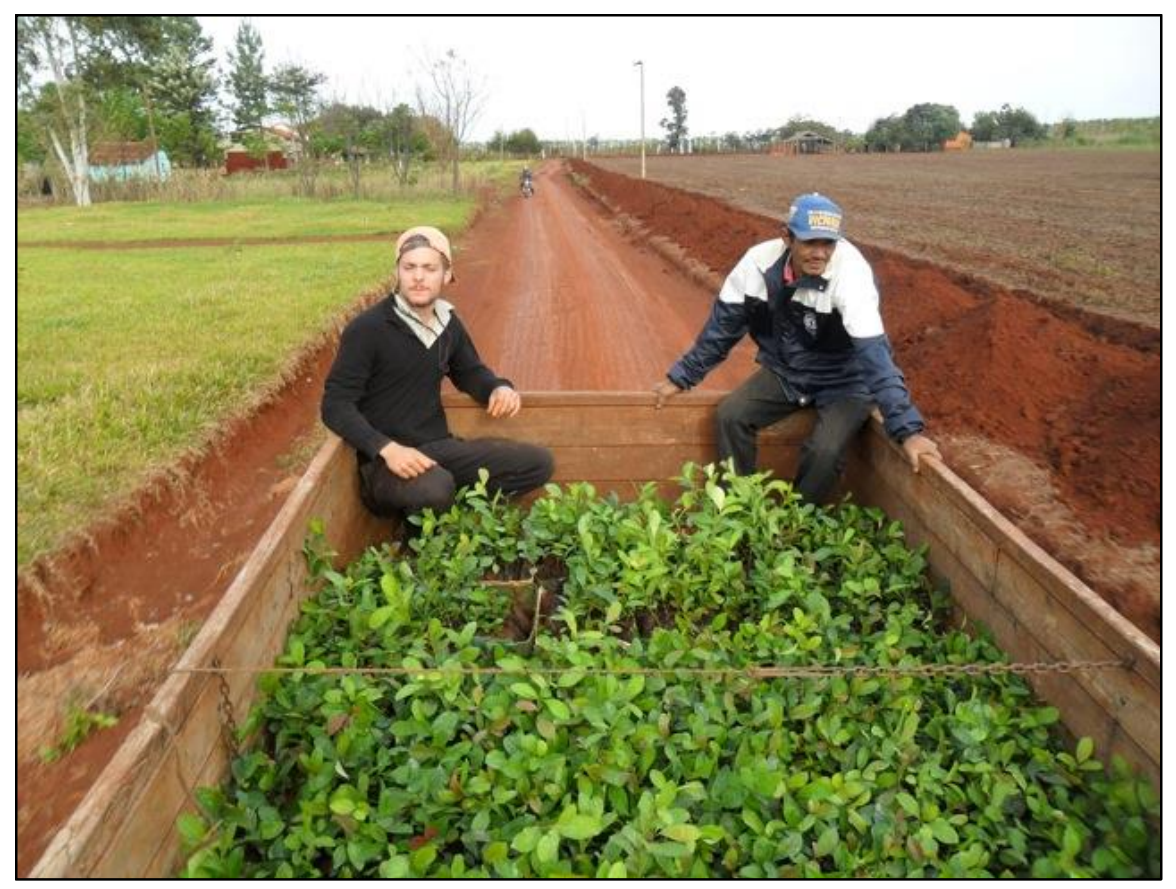

Figure 14: Community and Peace Corps volunteers assisting with yerba mate seedling delivery. (Photo by Brian Pattullo)

In total, six of the local nurseries combined provided 31,898 yerba mate plants to the project for a price of 800 Gs. per unit. Two local nurseries were unable to provide plants to the project because one nursery operator had previously arranged a contract with a separate buyer and the other had an overall poor quality product. Once the quantity of locally available plants was finally determined by exhausting the available acceptable supply, a seventh large-scale yerba mate nursery was identified in a town approximately 30 kilometers away and remaining funds allowed for the purchase of an additional 24,000 plants at a price of $600 \mathrm{Gs}$. per unit.

The distribution process took a full three weeks from May 23, 2011 to June 11 including 1.5 days lost to rain, and 1.5 days lost to the truck breaking down. The truck and its driver were based out of Libertad del Sur and negotiations concluded with an 
agreement for 300,000 Gs. today to cover the drivers time as well as fuel. The truck was less than ideal as it required a push start about $50 \%$ of the time, the ease of doing so was highly dependent on the number and strength of volunteers present. However, the local hire allowed for a lower cost in fuel and labor, greater scheduling flexibility, reliability in commitment, as well as familiarity and ease of traveling within the community.

In total, 56,017 yerba mate plants and 8,147 native trees of a variety of species selected for their growth characteristics compatibility with yerba mate. After two families withdrew from the project, all plants were distributed among 92 remaining separate households with observed average planting density of 1,800 plants per hectare that suggests an approximate coverage of 30.8 hectares in mixed agroforestry systems.

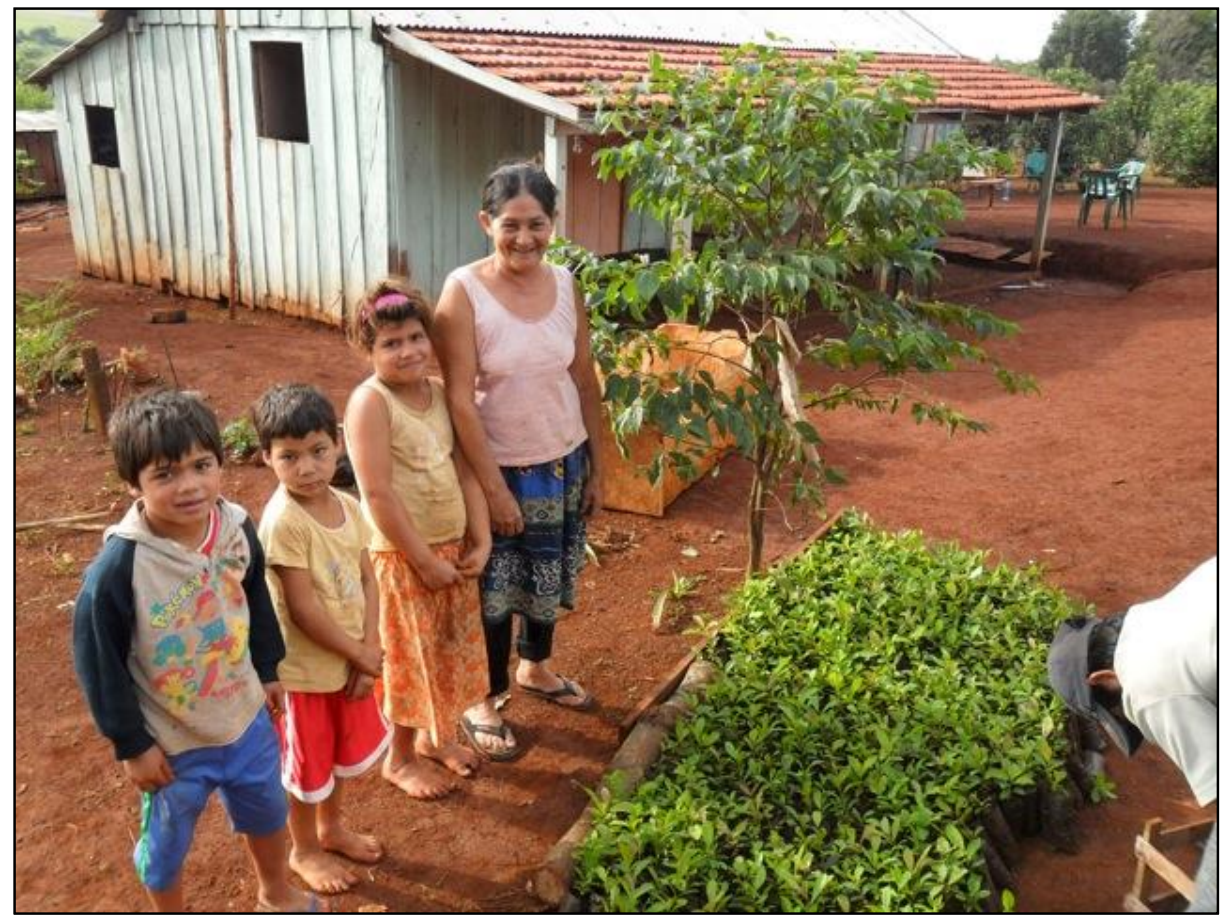

Figure 15: A participant family receiving delivery of yerba mate seedlings. (Photo by Brian Pattullo) 


\section{v. Agroforestry with Yerba Mate Project: Investigation}

Upon completion of delivery, I began follow up visits to a representative sample of households to verify plantings and visit individual farmers to observe differences in planting styles. In order to satisfy evaluation requirements for Fondos, the funding organization, and to collect personal research data, I measured heights of 3,060 yerba mate plants at a total of 26 locations on two separate occasions between August/September and October/November 2011. I also performed basic mortality surveys of 2,865 yerba mate plants at 22 additional locations. This represents a 5.5\% sample rate for growth calculations, and $10.6 \%$ sample for mortality estimates from exactly half of the participant households. I averaged a 10\% sample at each location based on

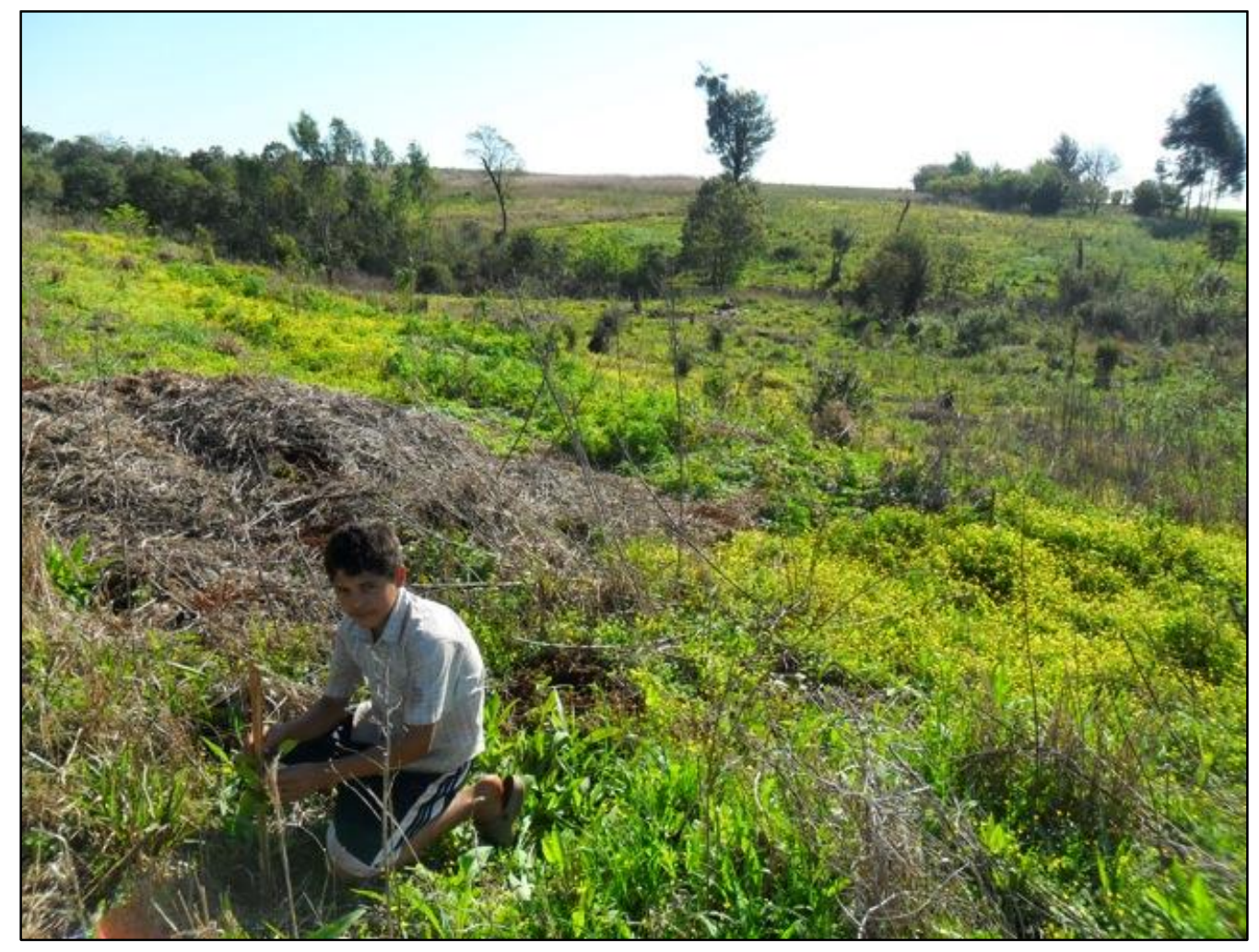

Figure 16: Research assistant measuring yerba mate in a field with vegetative cover. (Photo by Brian Pattullo) 
records of quantities that individual participants received. Planting sites were randomly selected and represented a variety of quantities of plants received, which also represented a varied level of participation in the trainings and volunteer efforts.

Consistently evaluating highly varied planting sites was a challenge. Stratified random sampling methods were followed by first identifying any separate strata within a planting site such as variations in exposure to elements and elevation characteristics, then randomly selecting planted rows for evaluation. Notes and directions to the selected study rows were carefully recorded, and the beginnings of rows were flagged to ensure a return to the same location months later where growth was calculated. Once the first line was measured, the sample continued two to three lines away from the last while following

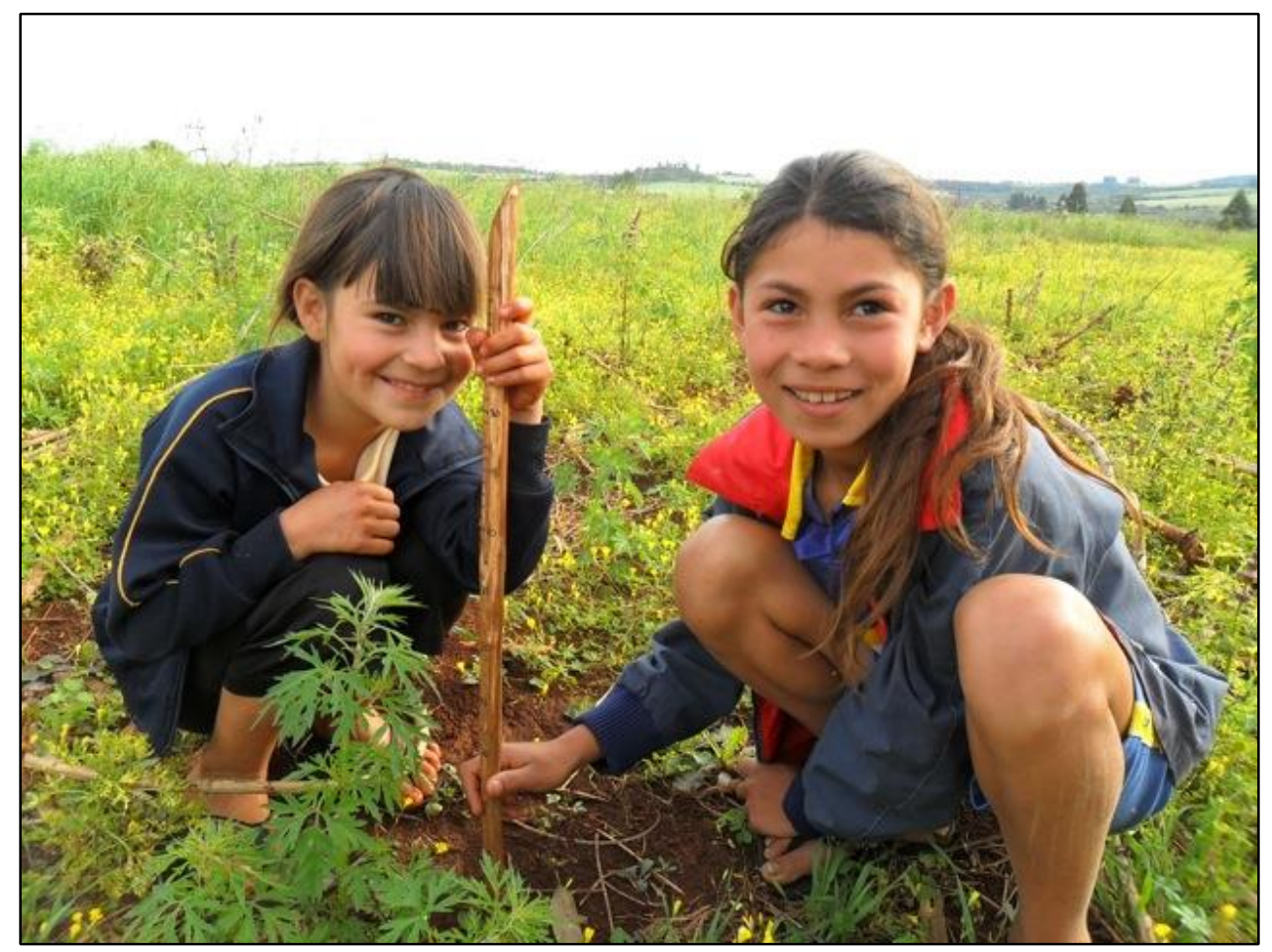

Figure 17: Research assistants helping to measure growth of yerba mate seedlings.

(Photos by Brian Pattullo) 
the same flagging and noting procedures. Field assistant volunteers of ages ranging from 7 to 50 were employed from the respective households to assist in measuring and describing the planting strategy. All measurements were taken with one durable homemade measuring device, and proper usage procedures were described to each assistant prior to the start of surveying.

Observations of planting styles including spacing, presence of weeds or crops, slope, presence of trees, orientation of planting rows, approximate planting date as well as presence of animals were all noted. All data was recorded into Microsoft Excel spreadsheets for ease of calculations of growth and general evaluation. Photos were also taken of each location for posterity, and copies of selected photos from each research family were provided to them as a token of appreciation for their assistance.

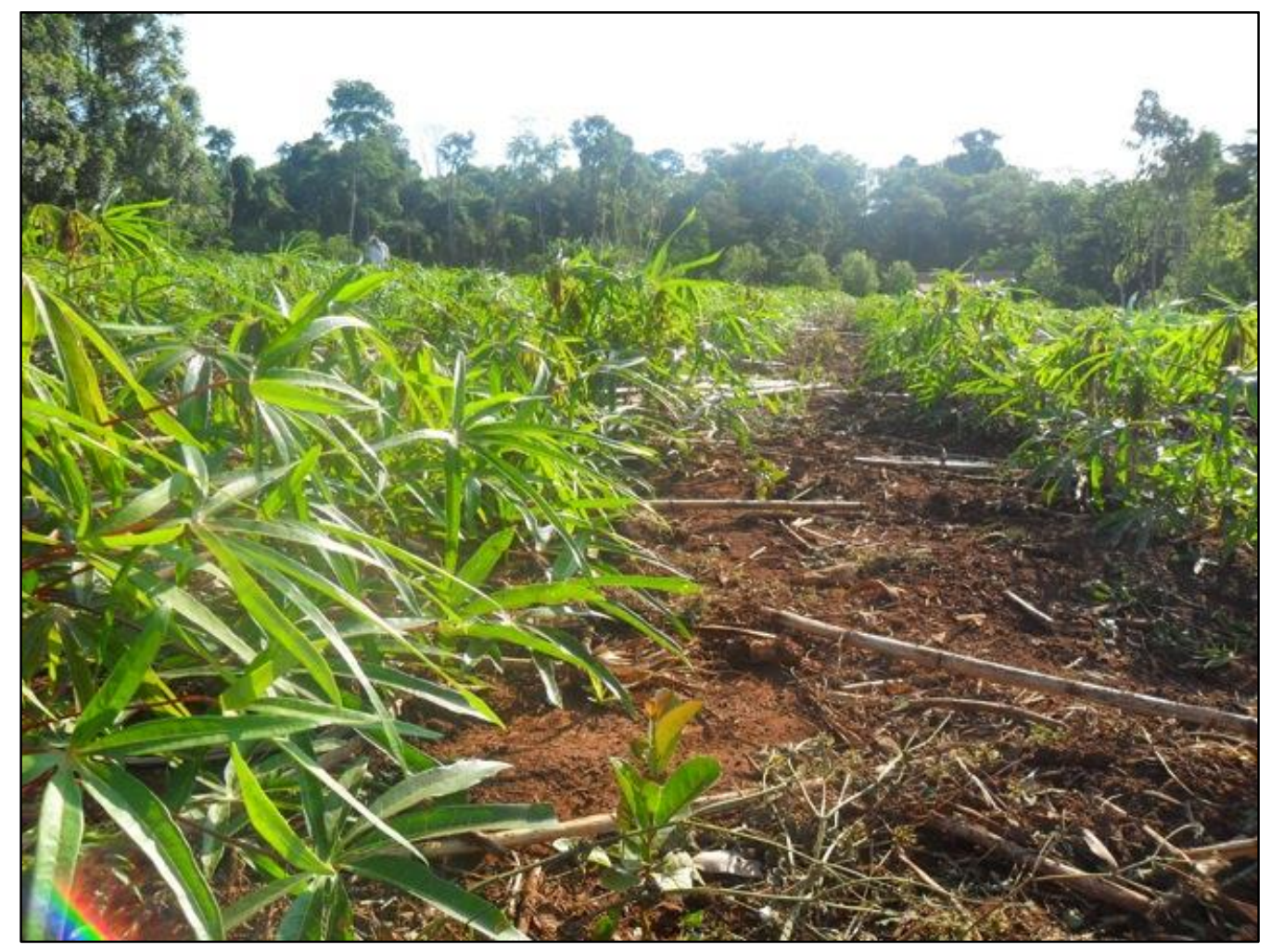

Figure 18: Yerba mate inter-planted with cassava. (Photo by Brian Pattullo) 
Formal interviews were conducted and recorded in a mix of Guarani and Castellano languages with 18 project participants. The interviews were then translated and transcribed into English. Questions focused on standard crops planted for sale and for home consumption, number of hectares owned, presence of a woodlot, fuelwood use, familiarity with yerba mate, income sources, future plans for farming strategies, as well as perceptions of ideal roles for outside organizations assisting the community. The Michigan Technological University Institutional Review Board for human subject research approved all 19 questions.

\section{vi. Agroforestry with yerba mate: Evaluation}

Evaluation of the collected data yielded preliminary indications of preferred planting styles, crop associations, as well as maintenance practices that showed correlation with decreased mortality rates and improved growth rates. First, and most apparent, was a strong correlation between maintaining ground cover around the yerba mate seedling. Ground cover was in the form of either weeds left around the planting site or crops adjacent to the site with either, or both, providing a minimum approximate $25 \%$ shading. Additional measures considered in this category included a method called arepuka, which involved the placing of two to three pieces of wood surrounding the plant protecting from direct sunlight as well as frost. While the data is not necessarily statistically significant, it is worth noting that the two individuals who consistently utilized the arepuka method experienced below average mortality rates of only $8.5 \%$ and $8.8 \%$. 


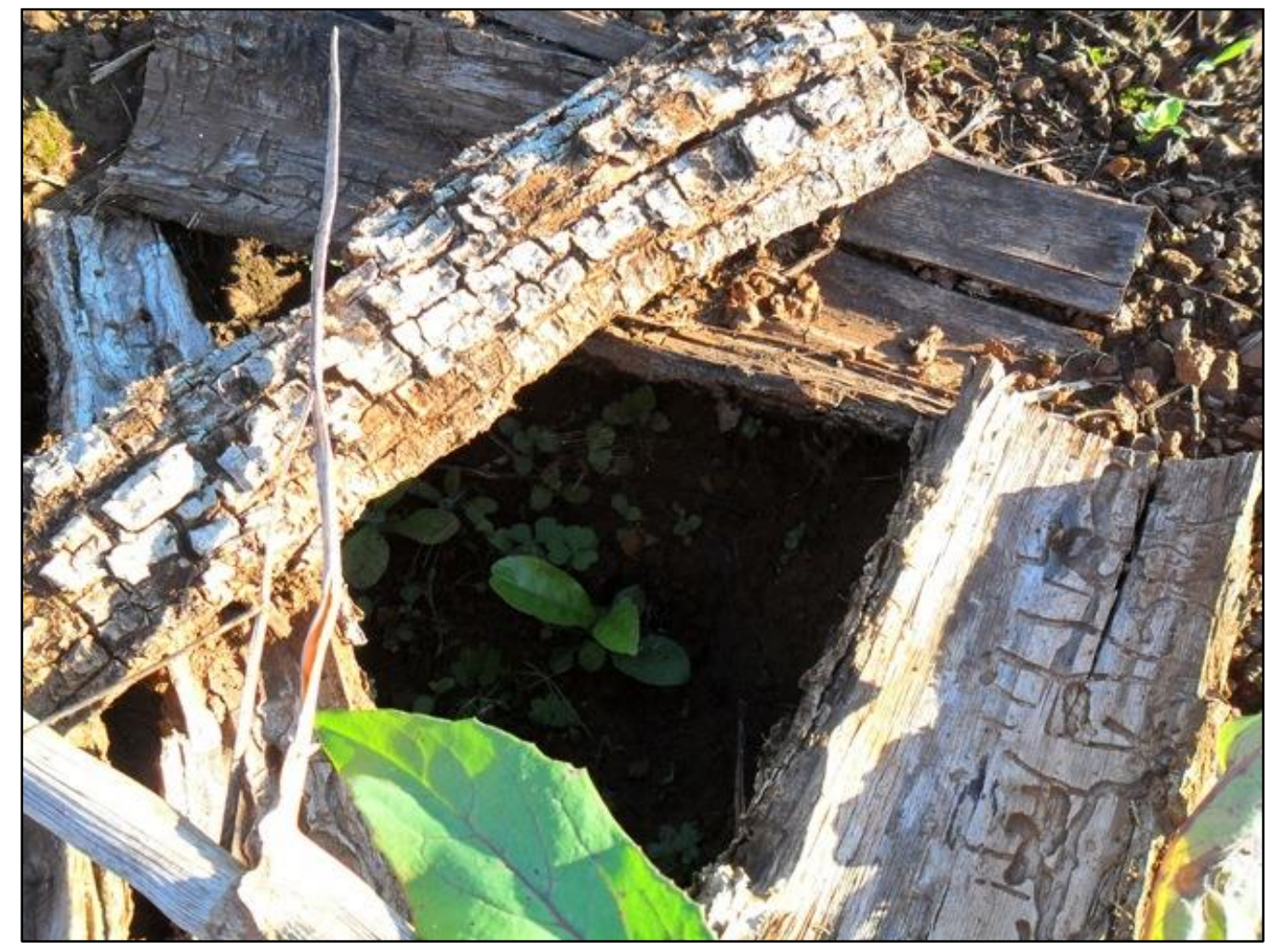

Figure 19: Example of Arepuka planting to provide some shade, minimize soil erosion, and maintain humidity. (Photo by Brian Pattullo)

Yerba mate plants observed in fields utilizing arepuka or vegetative cover experienced mortality levels at an average of $20.59 \%$ in the initial six months after planting. Those yerba mate plants observed with less than $25 \%$ vegetative cover around the planting site experienced mortality rates of $40.99 \%$, nearly double the rate of those with protection. This was a useful finding as a question raised during initial trainings was whether or not fields should be cleared of competing vegetation consistent with standard weeding practices utilized for other crops such as corn and mandioca/cassava. This finding is also in contrast to native tree planting styles that, through anecdotal observations, tended to have roughly equal survival rates regardless of 


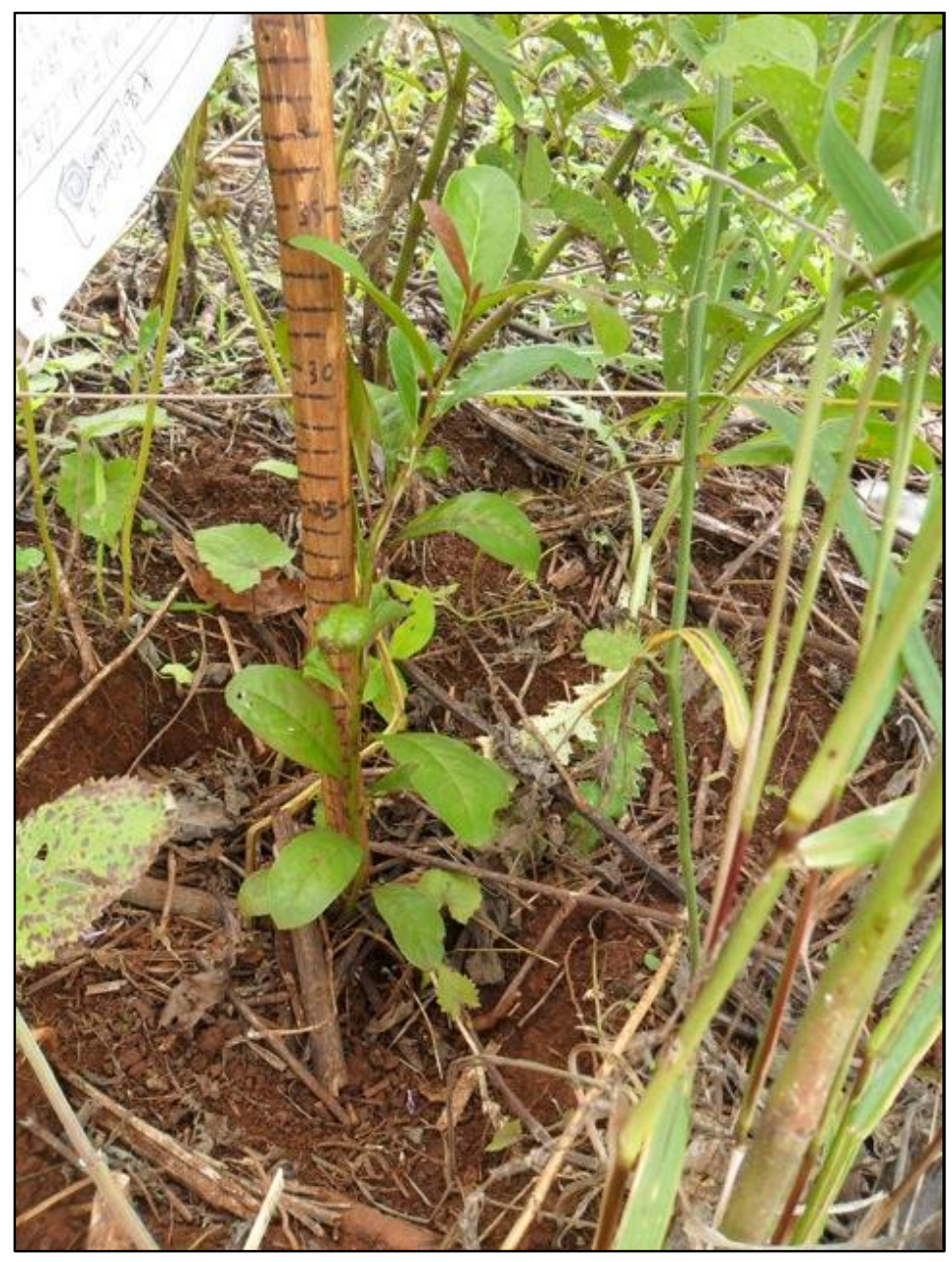

Figure 20: Yerba mate grown with vegetative cover adjacent to the plant being measured with the homemade measuring stick. (Photo by Brian Pattullo)

surrounding vegetative cover. However, the native trees tended to grow more vigorously without competing vegetation.

A primary challenge to statistical analysis of the data is that there is high variability of conditions between study sites. Variables include potential threats to establishment of yerba mate seedlings such as severity of slope, quantity of free-range chickens, presence of tree windbreaks, proximity to soccer fields, timing of planting in 


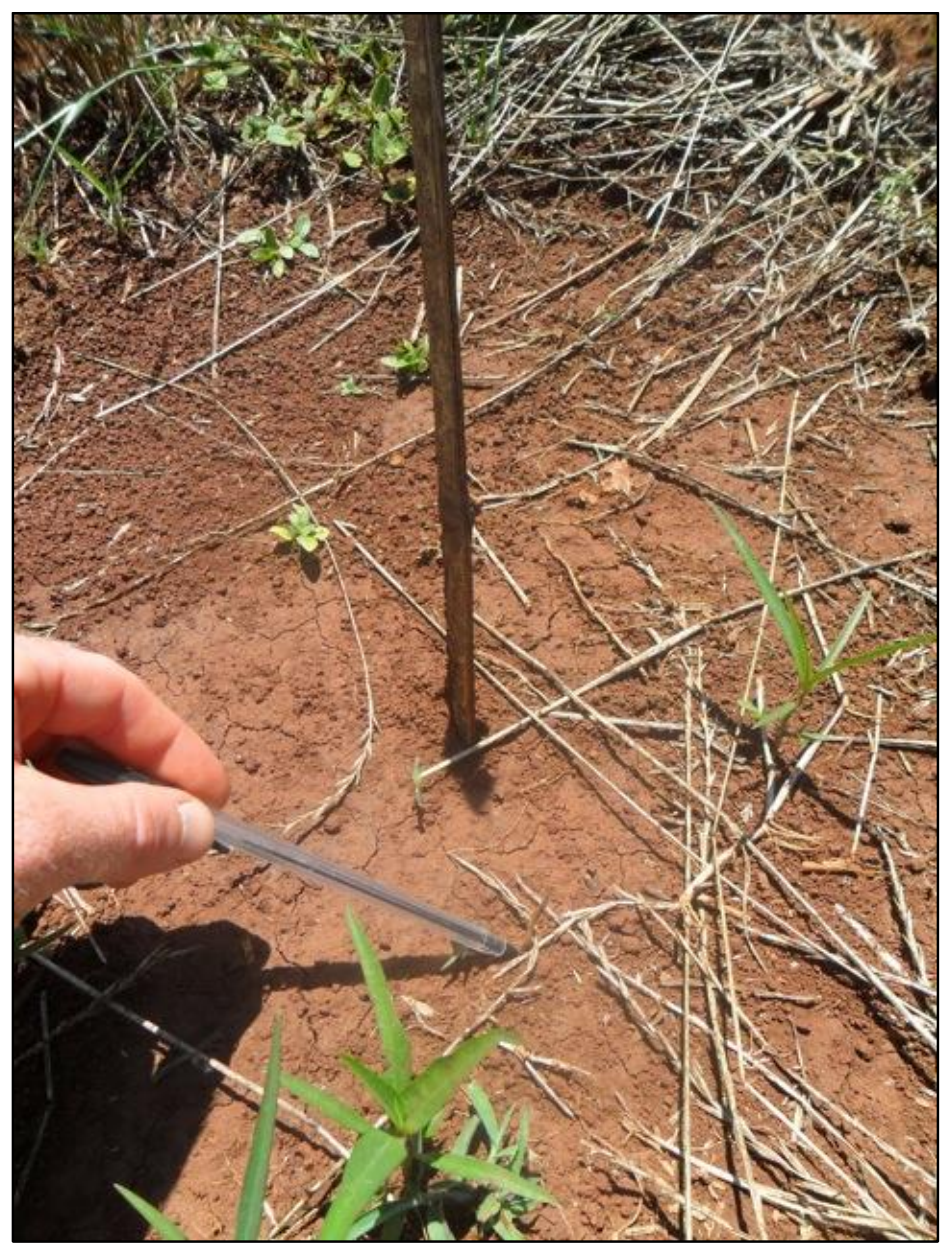

Figure 21: Dead yerba mate with below 25\% vegetative cover at planting site. (Photo by Brian Pattullo)

relation to previous and subsequent rainfall, crop history, soil organic matter content, and even social factors such as different levels of participation in project trainings relating to a variable degree of exposure to technical information and general appreciation of the project. However, the data collected and the observations captured provide some indications of relationships between observed conditions and plant growth and mortality rates. 
Trees forming windbreaks at the south end of two yerba mate plantations may have been effective in mitigating damaging impacts of frost. Libertad del Sur is in a gently sloping valley where there is potential for frost during winter months. Winter winds originating from the south typically are colder and present the greatest threat to frost exposure. A severe frost event occurred in August 2011 that resulted high rates of mortality and damage to many yerba mate plants in the lower elevations of the valley. Two locations were characterized by similar planting styles, elevation levels, and most other variables to neighboring planting sites with the exception of a treeline windbreak established at the south end of the yerba plantation. Plants at these two locations experienced mortality rates of only $7.3 \%$ and $13.3 \%$ overall while their immediate neighbors without similar windbreak protection experienced $20 \%$ to $30 \%$ mortality rates in that frost event with many more plants exhibiting superficial damage. This observation

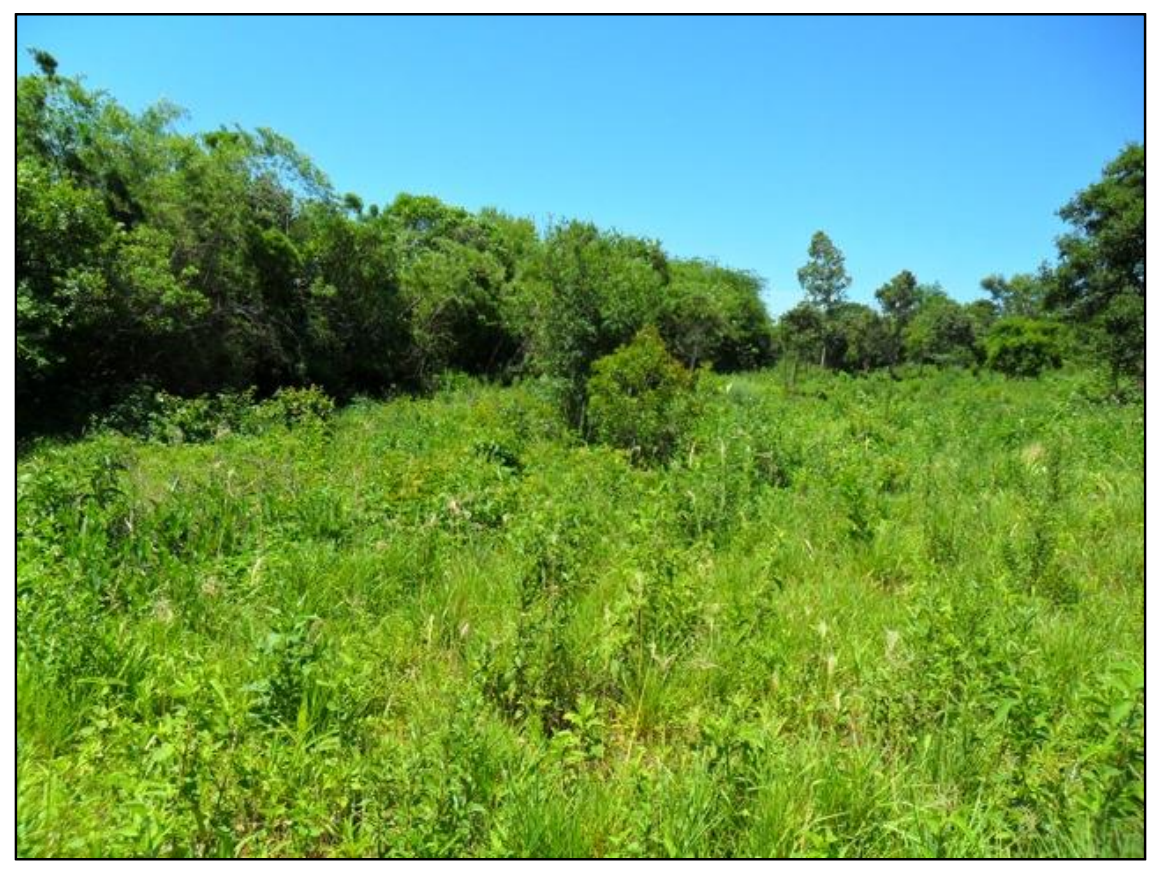

Figure 22: Windbreak oriented East to West at South end of yerba mate plantation. (Photo by Brian Pattullo) 


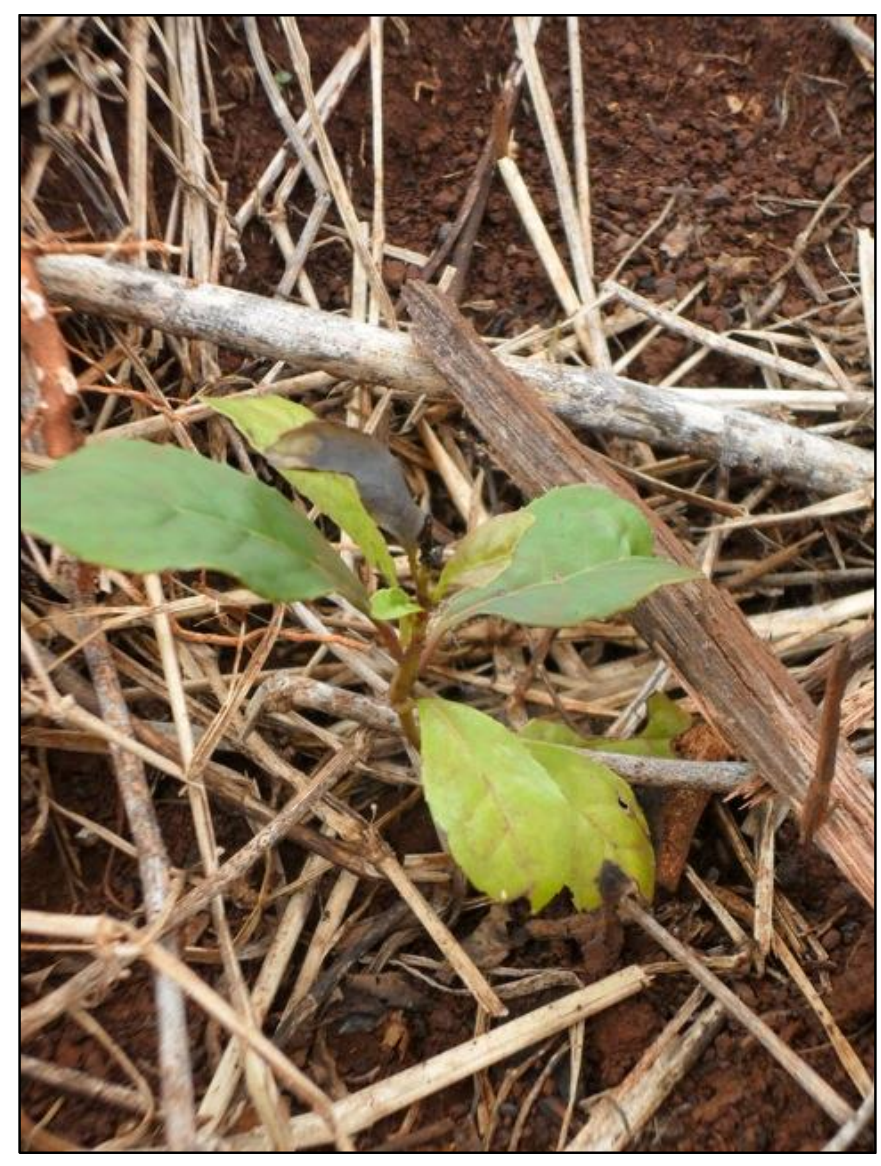

Figure 23: Superficial frost damage on exposed yerba mate seedling. (Photo by Brian Pattullo)

warrants further research and could be valuable in incentivizing increased use of tree plantings for windbreaks in similar sites.

There appears to be a correlation between increased exposure to animals such as pigs and chickens and increased plant mortality rates. This does represent an intuitive relationship, however, the significance is often overlooked when considering planting location and appropriate planting style. In areas where animals are permitted to graze freely, planting sites should be located at a sufficient distance from the standard feeding areas to avoid being stepped on or eaten. Where this is not possible, simple protection 
such as stakes placed around the plants would be sufficient to minimize potential damage from foraging chickens. More sturdy protection should be considered in situations where pigs are of concern. Cattle should not be allowed near yerba mate or native tree planting sites.

The practice of integrating trees with yerba mate in agroforestry systems within the same field as recommended in the training events was not consistently practiced by participants. Several forms of associating native trees beneficially with yerba mate were presented to participants including mixed planting, windbreaks, and live fence systems. While many incorporated these strategies, many chose to plant their native trees in portions of their property separate from the yerba mate. It is important to note, however, that with two exceptions, all participants visited for this research had planted their native trees somewhere on their property between June and September 2011. Future projects seeking to promote integration of native trees and ensure their plantation may want to consider achieving visual confirmation of native tree planting prior to delivery of yerba mate plants. This level of planting verification was not feasible in this project given time constraints inherent to Peace Corps service rotations of two years.

The interviews were effective in providing anecdotal evidence of agricultural, environmental, social and economic issues in the community. However the small sample size failed to provide significant correlation in responses to most themes. An additional trend worth noting is the variability in conversations when formal interviews were being recorded versus participants candor exhibited in informal conversation. Participants were generally less likely to provide responses that could be perceived as disparaging to other individuals, groups and aid organizations while being recorded than they were before or 
after recording. Sociologically, this may be a result of practices of Stroessner's Pyragues reporting such commentary to government agencies. This is assumed a possibility because I was called "letrado" (clever/cunning) by several participants after formal interviews who, at least somewhat jokingly, expressed concern that I was trying to get them in trouble by asking questions regarding perception of aid organizations and a few who even mentioned Stroessner-era policies.

A final definitive and unfortunate finding from this research is the negative impact of droughts on yerba mate. All data and observations involved in the above analysis were collected between June and November 2011. From December to March 2012 Paraguay experienced a severe drought severe enough for the country to declare a state of emergency by the end of February. This disastrous drought caused an estimated loss of $50 \%-60 \%$ all crops in the region. The result to this project was an estimated loss of at least $80 \%-85 \%$ of the yerba mate plants. This loss prohibited further research I had intended during my third year of service extension to determine likelihood of continued adoption by smallholder farmers of the agroforestry with yerba mate systems.

\section{Chapter V: Discussion}

The preceding pages have provided insights to many aspects of my experience as a Peace Corps agroforestry volunteer in rural Paraguay. I find it hard, as do many other volunteers, to consider my experience successful in general. As in many other aspects of our personal and professional lives, people have a tendency to be their own toughest critics. It is safe to say that this particular effort outlined above to implement agroforestry with yerba mate into 92 households within the community failed. The near four-month 
drought played a strong role in that. However, there were individuals who had lost up to $81 \%$ of their plants before the drought even started. Is that a representation of my own personal failure to prepare those farmers? Is it a failure of the project that someone who was apparently disinterested or ill prepared even received the opportunity?

It is difficult to evaluate success in an environment with so many variables. As Peace Corps's development strategy attempts to impact long-term change through volunteer service periods of only two years, is it possible to accurately and effectively measure success? When considering the nature of Peace Corps and development work in general, how can individual and organizational impact be isolated and measured amidst countless other variables at levels ranging from an individual family to a nation? In reflecting on the circumstances in which a community such as Libertad del Sur formed, is there a realistic understanding of what success would look like?

Paraguay's history has created a culture and society that is its own and the same can be said for any country. As the adage says, "To know where you're going, you have to know where you've been", it is important to consider relevant aspects of history for any organization involved in development work. This lesson can be seen in the adoption of soy across Paraguay. Many authorities agree that since the War of the Triple Alliance Paraguay has been run by a minority that seeks to preserve their own power at the expense of the majority. As Paraguay's soy industry rose to the $4^{\text {th }}$ largest exporter in the world it did so following historical trends with foreign actors and benefactors of political alliances receiving much of the profits, while campesinos struggled to hold on to their lands. Is the soy industry appropriate for this country? It has been beneficial for some, but destructive to many. This raises many questions, including what socio-economic 
programs should be implemented that might encourage more equitable distribution of the costs as well as benefits among the population?

In a political environment that continues to be criticized for failure to truly promote policy that is beneficial for much of the population, organizations involved in development work undoubtedly have an important role. Given the disconnect in goals identified here between many of the poorer segments of the Paraguayan population and the government, as well as with NGOs, it is important for development organizations in particular to understand not only their role, but also how their role may be perceived by beneficiaries. Issues such as insecurity of land tenure has an impact on a community not only in terms of willingness to adopt new practices, but it may also drive internal conflict within a community that is not immediately recognizable and could prevent an organization from achieving their desired impacts.

Peace Corps volunteers have an ability to gain a unique perspective of the communities in which they work. By living within a community among families to whom they are dedicated to serve for two years, they have the potential to gain an understanding of the nuances of internal social dynamics that others with more limited exposure may not readily perceive. Integration into a community must be approached carefully though as variables exist that could cause a volunteer to feel alienated either from their organization or from their community should expectations, realistic or otherwise, of either group not be realized.

Evaluation of this project suggests that development agencies seeking to operate in developing countries should seek to utilize Peace Corps volunteers as resources to gain better understanding of true needs for communities in which they serve. Volunteers can 
be of great value in bridging logistical and cognitive disconnects that occur between organizations and communities. Aid organizations can serve to offer commodity and funding resources that volunteers are otherwise lacking because of Peace Corps regulations and funding limitations. By encouraging these inter-organizational relationships, volunteers can serve to improve tacit and explicit knowledge flow between all parties and serve to foster lasting productive relationships between organizations and communities even after a volunteer has completed their service.

As seen in Libertad del Sur, follow-through is crucial to the success of not only the project at hand, but to that of future projects. Numerous organizations operating in Libertad del Sur received a lot of criticism from many community members who saw them promoting goals not necessarily complementary to those of the community, providing only enough resources to start a project, and ultimately failing to follow through with no key stakeholders tied to project success. Organizations considered the community members themselves to be stakeholders, however, those community members often either lacked understanding of their status in that role, or simply lacked necessary technical knowledge to follow through without external support. The adopters of the poroto japonesa (Japanese bean) are a great example of this issue as many of them became frustrated with wasted time and effort. Not only did those individuals feel increasingly reluctant to adopt other new strategies, but their neighbors who saw or simply heard the rumors of their troubles also became less trusting of outside projects.

In considering this overall situation is it valid to consider the agroforestry project a success in that people at least tried something new? Participants heard the message being promoted on behalf of numerous environmentally focused NGOs operating within 
the region, local yerba mate industry representatives, and their own neighbors who had successfully produced and sold large quantities of yerba mate from their own tree nurseries. These smaller successes must be present in the consideration of any socioeconomic development project, and indeed are highly valued by Peace Corps.

I was not able to revisit Libertad del Sur in my third year to perform follow up research to identify how many individuals had continued integrating additional quantities of yerba mate into their farm systems. I was able to visit briefly on several occasions and witnessed that all tree nurseries remained in production of yerba mate plants and at least 5 of the 6 visited were successful in identifying their own markets for sale of the plants in 2012. Conversations with two of those individuals indicated that they had sold plants to their neighbors at reduced cost to help them replace the plants they had lost during the drought. I sincerely feel that this last fact represents a changing attitude and atmosphere within the community. It is doubtful that the committees will seek to assist each other any time soon, but there are indications of change at the smaller scale, which is how all change begins.

I can point to several examples in particular of small successes that were achieved through the larger project goal's activities. After the first required training that focused on the importance of reforestation in protecting rivers and watersheds was finished, two individuals who lived along the local river (Mboi $\mathrm{Ka}$ 'e) asked if they could receive more native trees than what they had originally signed up to receive in order to plant near the river. They were asked to confer with their neighbors to identify additional demand and report the total amount desired. They followed through and requested a total of approximately 1,600 additional native trees between just seven families. 
A second example is seen in the adoption of micro-scale yerba mate nurseries by at least 5 of the participants who attended the nursery training offered in March, 2011. By emphasizing low cost and small-scale implementation strategies of locally available resources and free seed collection, several individuals who had indicated previous reluctance because of perceived prohibitive costs successfully began independently producing their own plants. This idea was reinforced during the subsequent formal trainings required by the larger yerba mate project. Individual adopters in a few instances shared what they learned with their neighbors who then constructed their own small-scale nursery independently of my assistance or initial awareness. I only discovered several of these independent nurseries because I performed follow up visits to project participants to

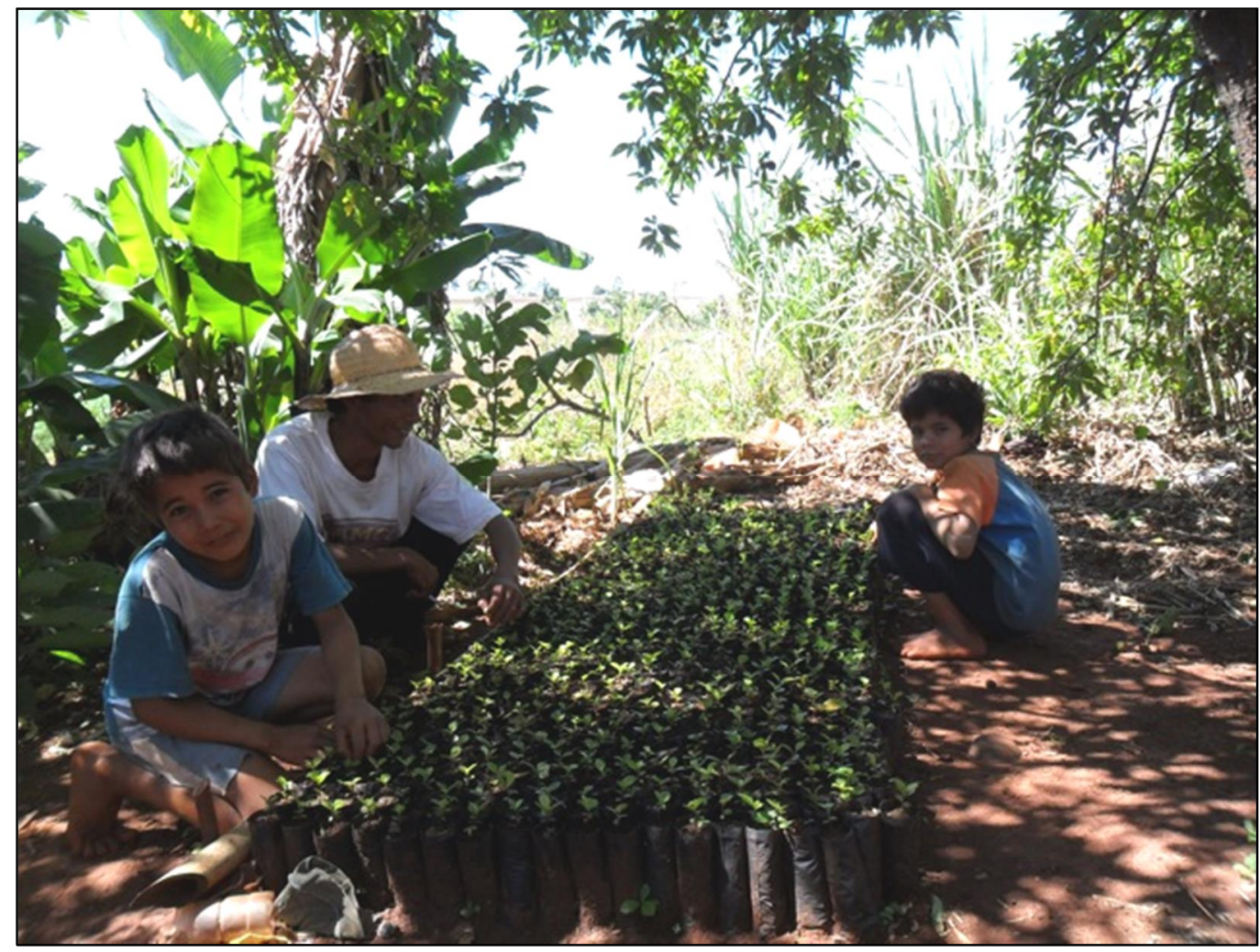

Figure 24: Small independently established yerba mate nursery in natural shade. (Photo by Brian Pattullo) 
evaluate their yerba mate planting. This example emphasizes the importance of technical trainings promoting independent adoption strategies to meet commodity supplies. The value of these trainings, as seen here, is not immediately realized in the number of attendees of a training event. The knowledge shared can have progressively greater impact over time through farmer-to-farmer exchanges if it truly is an appropriate strategy for a community.

These examples may seem relatively insignificant in a cost benefit analysis, but this typifies the developmental strategy of Peace Corps. In the shadow of a large failure, there are many bright spots such as these. How do these aspects factor into a larger measure of success?

The yerba mate agroforestry project emphasized the importance of collectively developing the local market for yerba mate, a crop that is arguably more sustainable, profitable, and appropriate to small holder farmers than the alternative dominant local market of soy. The desire for increased adoption of yerba mate was voiced by the majority of smallholder farmers but financial and logistical constraints prevented most from doing so. By providing these commodities in association with trainings emphasizing the benefits of sustainable agroforestry practices, organizations were granted access to potential stakeholders to help promote their goals of reforestation, protection of remnant forests, and seeking to restore natural environments conducive to biodiversity preservation. 


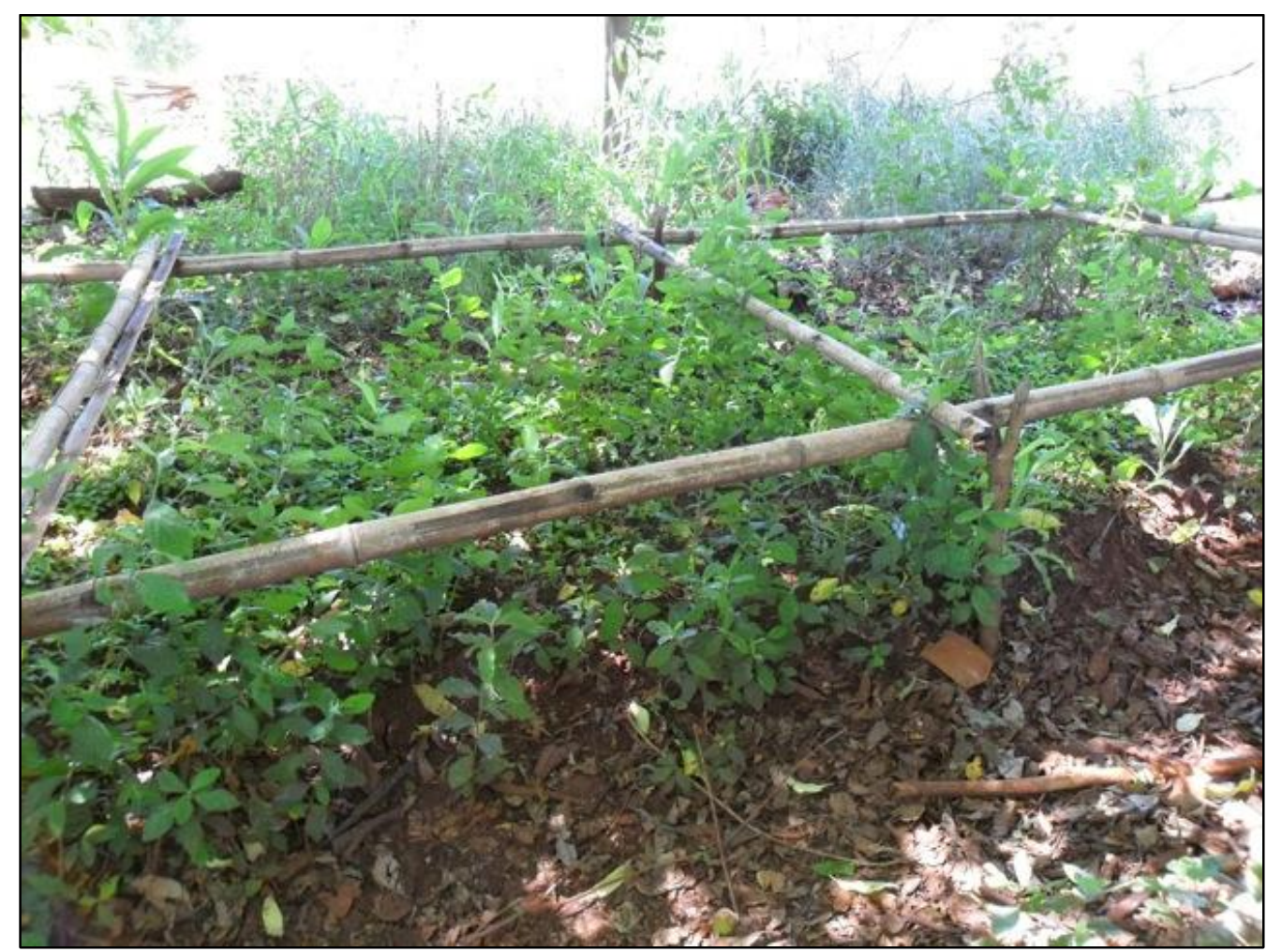

Figure 25: Small independently established yerba mate seedbed. (Photo by Brian Pattullo)

Similar projects had been attempted in the community but typically provided commodities on credit, to be paid back upon future harvests. The provision of plants as loans had inherent limitations to the quantity of participants for fear of risk and lack of confidence in organizations' continued assistance. A question for aid organizations is whether investment of such projects is worth future debt collection and monitoring costs, or if an investment on in a project such as the yerba mate agroforestry project is a more valuable towards achieving long term goals given observable yet difficult to quantify impacts seen resulting from this project?

The impact of this project can be seen in the results of the 18 formal interviews that identified further demand of at least 33 hectares of yerba mate plantation solely 
among the interview sample group. Among them, four expressed intentions or had already started their own tree nursery to meet their supply, four expressed willingness to purchase the plants, and the rest were uncertain as to how they may attain them. Additionally, nearly all informants reported desires to plant more native trees around their properties, particularly in or around the yerba mate plantations. These results indicate an increased willingness to act on the implementation of this promoted practice within the community. Prior to the project, practically no one expressed willingness during the first round of tree surveys to purchase yerba mate plants because of presumed prohibitive costs. However, subsequent to the efforts of nursery promotion, trainings, and overall push in momentum by the project, these individuals were willing to invest in their future with many emphasizing the strength of collective market potential should many in the community enter yerba mate production.

Assessing long-term sustainability of interest and practice in yerba mate agroforestry strategies in this community can only be done with time. The impact of the 2011-2012 drought on this matter is unclear. However, it is clear that this project was successful in not only raising awareness but also interest in the practice. As all parties involved agreed that the principle of the project was appropriate and pre-drought mentality appeared to expect expansion, it is safe to say that this form of mutually beneficial incentives has the potential to be a feasible strategy of achieving environmental development goals in this type of community. 


\section{Bibliography:}

Abramson, Evan. 2009. Report: Food Crisis. NACLA Report on the Americas. https://nacla.org/soyparaguay.

Babbie, Earl. The Sociological Sprit - Critical Essays in a Critical Science. 2nd. Belmont, CA: International Thomson Publishing, 1994. Print.

Beets, W. Raising and Sustaining Productivity of Smallholder Farming Systems in the Tropics. AgBé Publishing. Holland. 1990.

Britannica. 2013. War of the Triple Alliance. Encyclopedia Britannica.

Encyclopedia Britannica Online Academic Edition. Encyclopedia Britannica Inc., 2013, Web. 29 Apr. 2013.

http://www.britannica.com/EBchecked/topic/442711/War-of-the-Triple-Alliance.

CDA - Center of Documentation and Archives for the Defense of Human Rights. 2008. Archives of Terror. Memory of the World Register - Paraguay.

www.unesco.org.

CIA World Factbook: Paraguay. United States Central Intelligence Agency. Web. 29 Apr. 2013. https://www.cia.gov/library/publications/the-worldfactbook/geos/pa.html

Correa, D. 2008. Determinants of Rural Non-Farm Employment and Income in Paraguay. Masters Thesis, University of Auburn. August, 2008.

Hanratty, D., Meditz, S. Paraguay: A Country Study. Government Printing Office U.S. Library of Congress. 1988. http://countrystudies.us/paraguay/47.htm

Dangl, B. 2012. A coup over land: The resource war behind Paraguay's Crisis. Upside down world. http:www.upsidedownworld.org. 2013.

Deininger, K., Olinto, P. 2000. Asset Distribution, Inequality, and Growth. Policy Research Working Paper series No. 2375. 2000.

DGEEC: Dirección General de Estadistica, Encuestas, y Censos. Compendio Estadístico Ambiental del Paraguay 2001-2011. Asuncion, Paraguay. 2013.

Evans, D. "Appropriate technology and its role in development." Appropriate technology for development: a discussion and case histories. Boulder, CO. Westview Press.1979. Print.

Economist. 2012. Author Unknown. The Never Ending War. The Economist. Dec. 22, 2012. 
Hetherington, K. 2009. Privatizing the private in rural Paraguay: Precarious lots and the materiality of rights. American Ethnologist. Vol. 36, No. 2. 2009.

(HCVF) High Conservation Value Forests. 2013. Executive Summary: HCVF in San Rafael. Web. 29 Apr. 2013.

http://www.hcvnetwork.org/resources/assessments/WWFch\%20(PY)\%20report\%20text(HCVF).pdf

Hoard, April. 2009. Saying No to Soy: The Campesino Struggle for Sustainable Agriculture in Paraguay. Monthly Review. Vol. 61, Issue 2. June, 2009.

Huang, C., Kim, S., Altstatt, A., Townshend, J., Davis, P., Song, K., Tucker, C., Rodas, O., Yanosky, A., Clay, R., Musinsky, J. 2006. Rapid loss of Paraguay's Atlantic forest and the status of protected areas $-A$ Landsat assessment. Remote Sensing of Environment. 2006.

INDERT Instituto Nacional de Desarrollo Rural y de la Tierra webpage. 2013. Politica Agraria en el Paraguay. http://www.indert.gov.py/web/index.php/201209-21-07-36-49/historia

Kempton, Willett, James Boster, and Jennifer Hartley.Environmental Values in American Culture. Cambridge, MA: The MIT Press, 1995. Print.

Kleinpenning, Jan M. G. Rural Paraguay, 1870 - 1963. Madrid: Iberoamericana, 2009. Print.

Leite da Costa, M., Dorr, A., Strassburger, R., Reys, M., Rossi de Freitas, L., 2011. How to increase the competitiveness of small soy farmers in Paraguay. Report submitted to International Association of Agricultural Economists (IAAE). 2011.

Lipsky, Michael. Street-Level Bureaucracy - Dilemmas of the Individual in Public Services. New York: Russel Sage Foundation, 1980. Print.

Malik, C. 1966. What Shall It Profit A Man. Columbia Journal of World Business. Summer 1966.

Nickson, A., Lambert, P. 2002. State Reform and the Privatized State in Paraguay. Public Administration and Development No. 22. 2002.

Ostrom, E., Burger, J., Field, C., Norgaard, R., Policansky, D. 1999. Revisiting the Commons: Local Lessons, Global Challenges. Science. Vol. 284. April, 1999. 
Peace Corps. 2013. Fast Facts. United States Peace Corps, n.d. Web. 29 Apr. 2013. http://www.peacecorps.gov/about/fastfacts/

Palau, T. Cabello, D., Maeyens, A., Rulli, J., Segovia, D. Refugiados del modelo agroexportador. Impactos del monocultivo de soja en las comunidades campesinas paraguayas. Asunción: BASE Investigaciones Sociales. October, 2007.

Rouquié, A. 1987. The Military and the State in Latin America. Berkeley: University of California Press. Berkeley, CA. 1987. Print.

Rulli, J., Semino, S., Joensen, L., 2006. Paraguay Sojero: Soy expansion and its violetn attack on local and indigenous communities in Paraguay. Grupo Reflexión Rural (GRR). http://www.non-gmfarmers.com/documents/Paraguayreport.pdf

Stadius, E. 2012. Land Reform Issues Intensify as Paraguay Enters Into a Political Crisis. Council on Hemispheric Affairs. June 22, 2012.

Transparency International. 2013. Corruption by Country/Territory: Paraguay. Web. 29 Apr. 2013. http://www.transparency.org/country\#PRY

Wharton, C. 1969. The Green Revolution: Cornucopia or Pandora's Box? Foreign Affairs. No. 47. April, 1969.

Winslow, R. 2012. Paraguay. Crime and Society: A Comparative Criminology Tour of the World. San Diego State University.

The World Bank. 2013. Paraguay Data. Web. 29 Apr. 2013. http:data.worldbank.org/country/Paraguay.

WWF. 2013. El Bosque Atlántico Del Alto Paraná. WWF Paraguay, n.d. Web. 29 Apr. 2013.http://www.wwf.org.py/que_hacemos/bosque_atlantico/ 